\title{
Atlantic salmon Salmo salar and ballan wrasse Labrus bergylta display different susceptibility to clonal strains of Paramoeba perurans
}

\author{
O. M. V. Dahle ${ }^{1,5}$, S. H. Blindheim ${ }^{1,6}$, A. Nylund ${ }^{1}$, E. Karlsbakk ${ }^{1,2}$, O. Breck ${ }^{3,7}$, \\ H. Glosvik ${ }^{3,5}$, L. Andersen ${ }^{4, *}$ \\ ${ }^{1}$ Department of Biology, University of Bergen, 5020 Bergen, Norway \\ ${ }^{2}$ Institute of Marine Research, 5817 Nordnes, Bergen, Norway \\ ${ }^{3}$ Marine Harvest ASA, 5835 Sandviken, Bergen, Norway \\ ${ }^{4}$ The Aquatic and Industrial Laboratory (ILAB), 5006 Bergen, Norway \\ ${ }^{5}$ Present address: Mowi ASA, Sandviksbodene 77, 5035 Bergen, Norway \\ ${ }^{6}$ Present address: The Aquatic and Industrial Laboratory (ILAB), 5006 Bergen, Norway \\ ${ }^{7}$ Present address: Norwegian Food Safety Authority, 5006 Bergen, Norway
}

\begin{abstract}
Amoebic gill disease (AGD), caused by the marine amoeba Paramoeba perurans, is an important disease of farmed Atlantic salmon Salmo salar L. in Norway. The use of wrasse as cleaner fish in salmon net pens raises questions about interspecies transmission of pathogens such as $P$. perurans. In this study, cohabitant transmission of clonal isolates of $P$. perurans between Atlantic salmon and ballan wrasse Labrus bergylta Ascanius was examined, using isolates originating from both salmon and wrasse. The challenges resulted in AGD in both species, although less severely in wrasse. The amoeba isolate originating from ballan wrasse was more virulent than that originating from salmon, suggesting $P$. perurans strain-related virulence differences. The isolate originating from salmon showed limited proliferation in bath-challenged wrasse and salmon, and limited transfer to cohabitants. Our results support previous observations suggesting that salmon may be more susceptible to P. perurans and AGD than ballan wrasse. Treatment of $P$. perurans infection in wrasse is challenging, as it is a strictly marine fish species. In this study, brackish water $(<15 \%$ seawater) treatment of AGD affected salmon and wrasse was examined. Both salmon and wrasse were treated for short periods ( $3 \mathrm{~h}$ and $24 \mathrm{~h}$ ), and treatment of wrasse over longer periods (3-5 d) was also examined. Short exposure to brackish water was not enough to remove $P$. perurans, although the $24 \mathrm{~h}$ treatment reduced amoeba levels. It was not possible to culture or detect $P$. perurans from wrasse exposed to brackish water for $3 \mathrm{~d}$, suggesting that this treatment would be effective in controlling the parasite.
\end{abstract}

KEY WORDS: Virulence $\cdot$ Neoparamoeba perurans $\cdot$ Susceptibility $\cdot$ Cleaner fish $\cdot$ Cohabitant transmission · Amoebic gill disease $\cdot$ AGD

\section{INTRODUCTION}

Cleaner fish, such as certain wrasse species and lumpsucker Cyclopterus lumpus L., are important for lice control in Norwegian salmon farms (Bjordal 1991, Skiftesvik et al. 2013, Brooker et al. 2018). Wrasse constitute a large proportion of the cleaner fish used by the aquaculture industry in Norway ( 30\%) and in

\footnotetext{
${ }^{*}$ Corresponding author: linda.andersen@ilab.no
}

2017, some 20 million wild-caught wrasse were used together with $\sim 0.6$ million farmed ballan wrasse (Directorate of Fisheries 2017). Most parasite species found to infect wrasse in a farm environment are host specific and will most likely not represent any threat to Atlantic salmon (Treasurer 2012). An exception is the parasitic amoeba Paramoeba perurans (syn. Neoparamoeba perurans; Feehan et al. 2013), the

(C) The authors 2020. Open Access under Creative Commons by Attribution Licence. Use, distribution and reproduction are unrestricted. Authors and original publication must be credited. 
causative agent of amoebic gill disease (AGD) (Young et al. 2007). This amoeba has been detected in some 18 fish species, including farmed Atlantic salmon and farmed and wild-caught ballan wrasse Labrus bergylta Ascanius (Karlsbakk et al. 2013, Oldham et al. 2016, Hellebø et al. 2017, Hvas et al. 2017, Steigen et al. 2018). The fact that a species is susceptible to $P$. perurans, however, does not necessarily mean that it will develop AGD, as shown for lumpfish (Haugland et al. 2017). At present, the factors that lead to differences in susceptibility and resistance have not been identified (Nowak et al. 2008, 2014 Crosbie et al. 2010, Marcos-López et al. 2017). One possibility is that the strains of the amoeba causing disease in ballan wrasse and salmon populations are host adapted and less virulent in unrelated hosts (e.g. salmon and ballan). In the present study, we ran cross challenges using 2 clonal P. perurans isolates from these respective hosts, examining differential hostparasite relationships by heterologous amoebae.

Due to concerns regarding both the sustainability of wrasse fisheries and pathogen spread, some companies have started rearing wrasse commercially on land. This makes it more feasible to produce pathogen free cleaner fish and to cover the increasing demand for cleaner fish without affecting wild stocks through overfishing. However, diseases also occur in intensive wrasse production, and the first AGD outbreaks in farmed ballan wrasse occurred in Norway in 2013, when 2 facilities were affected. Macroscopic signs were not as apparent as in Atlantic salmon, but molecular analyses confirmed the presence of $P$. perurans and gill lesions were seen histologically (Karlsbakk et al. 2013).

Freshwater bathing has been demonstrated to be an effective treatment for AGD in salmonids (Munday et al. 2001, Parsons et al. 2001, Powell et al. 2001, Adams \& Nowak 2004, Adams et al. 2012, Oldham et al. 2016). However, ballan wrasse is a strictly marine species, and freshwater treatment is therefore not a feasible option. Hydrogen peroxide may be used to treat AGD, but gill pathologies can lead to elevated mortality at high temperatures (Oldham et al. 2016). Treatment with brackish water should be much less damaging to the fish. It was shown in 2013 that salinities below $20 \%$ for $24 \mathrm{~h}$ could kill the amoebae in vitro (E. Karlsbakk pers. obs.). AGD in wrasse has subsequently been treated by commercial wrasse producers at land-based facilities using brackish water $(<15 \%)$ for $7 \mathrm{~d}$. The duration of the treatment was based more on precautionary concerns from $P$. perurans PCR results than on exact knowledge regarding amoeba survival.
In this study, cohabitant transmission of clonal isolates of $P$. perurans between Atlantic salmon and ballan wrasse was examined, with isolates originating from both salmon and wrasse. The aims were to reveal amoeba (i.e. strain) or host (i.e. species) related differences in the host-parasite relationships, including amoeba shedding from infected fish. A secondary objective was to examine the duration of brackish water treatment necessary to treat AGD and to remove P. perurans in ballan wrasse. Shorter treatments would reduce labour costs and freshwater use during treatments.

\section{MATERIALS AND METHODS}

\subsection{Paramoeba perurans isolates}

Paramoeba perurans isolates were obtained from farmed Atlantic salmon Salmo salar L. and farmed ballan wrasse Labrus bergylta Ascanius. Amoebae from Atlantic salmon were isolated in January 2014 from fish brought to the aquatic research facility ILAB, in Marineholmen, Bergen, from sea cages in Bjørnefjorden, a fjord near Bergen (Smørås 2014). AGD-like lesions (white mucoid patches) and amoebae were observed on the gills of some individuals. Amoebae were isolated and a clonal strain hereafter referred to as ' $\mathrm{SS}$ ' (= UiB isolate no. H03/14Pp) was established and maintained in culture. The clonal isolate had been kept in continuous culture for 9 mo before it was used in the present challenge study.

Ballan wrasse were reared at a land-based facility, the Institute of Marine Research station at Austevoll, near Bergen, Norway. In 2014, some lethargic juveniles showing signs of respiratory problems were seen, and 8 individuals (16-24 g, 10.5-13.2 cm) were examined for amoebae. The fish were killed by a blow to the head, and gill tissue swabbed onto malt yeast agar (MYA: $0.01 \%$ malt extract, $0.01 \%$ yeast extract, $2 \%$ Bacto agar, 34\% salinity seawater; Crosbie et al. 2012) in order to isolate amoebae. Amoebae were isolated from 4 of these 8 fish, all of which displayed macroscopically visible gill lesions (patches). A clonal strain hereafter referred to as 'LB' (= UiB isolate no. H04/14Pp) of $P$. perurans was produced from one of these fish and maintained in the laboratory for $6 \mathrm{wk}$ prior to the challenge.

\subsection{Isolation, maintenance and cloning of $P$. perurans cultures}

Amoebae were isolated by swabbing infected gill pieces directly onto MYA plates (Crosbie et al. 2012), 
which were subsequently covered by a layer of autoclaved seawater. The amoeba cultures were incubated at $16^{\circ} \mathrm{C}$ in a SANYO MIR-554 (SANYO Electric) incubation chamber. Sub-culturing was done every $10-14 \mathrm{~d}$, by passing supernatants to new plates or to $75 \mathrm{~cm}^{2}$ cell culture flasks with malt yeast broth (MYB: $0.01 \%$ malt extract, $0.01 \%$ yeast extract, seawater of $34 \%$ salinity; Haugland et al. 2017).

Clonal strains of $P$. perurans from Atlantic salmon were obtained from polycultures of amoebae in MYB by preparing a 1:10 dilution series of $200 \mu \mathrm{l}$ amoebae suspension with autoclaved seawater in 96-well cell culture plates. Based on amoeba counts, dilutions were made so that the final volume transferred to cell plates would contain low numbers of amoebae, ensuring that some wells would contain one amoeba only. Fifty $\mu \mathrm{l}$ of MYB was then added to each well, and the plates were incubated at $16^{\circ} \mathrm{C}$. Every well was thoroughly studied using an inverted microscope (Leica), in order to ensure that it contained an individual amoeba only; wells with more than one amoeba were disregarded (Nylund et al. 2018). The wells were observed daily. Fourteen days after inoculation, suspensions from wells with adequate amoeba growth were transferred into $25 \mathrm{~cm}^{2}$ cell culture bottles. Five $\mathrm{ml}$ of MYB was added and and bottles were incubated at $16^{\circ} \mathrm{C}$.

Clonal strains of $P$. perurans from ballan wrasse were obtained by removing a small volume $(100 \mu \mathrm{l})$ of free-floating amoebae from a primary polyclonal culture and spreading these onto a new MYA-plate. The resulting low density of amoebae allowed single amoeba to be collected using $100 \mu$ pipette tips, and transferred to new MYA-plates. This operation was done using an inverted microscope (Leica). The obtained monoclonal cultures were further cultured and sub-cultured in cell culture bottles with MYB.

Identification of the amoeba clones was verified by PCR and sequencing (see Section 2.9).

\subsection{Splitting of amoeba cultures prior to challenge}

To obtain sufficient numbers of amoebae for the bath challenge experiments, each clonal strain was grown in several $75 \mathrm{~cm}^{2}$ cell-culture flasks in the weeks prior to the challenge. Free-floating amoebae in MYB were then transferred to new cell culture flasks 2-3 times a week and the remaining adherent amoebae in the initial cell flasks were washed with autoclaved sea water and new MYB was added. On the day of challenge, all amoebae were collected using a cell scraper to detach the amoebae from the bottom of the cell culture flasks. The contents of all bottles were pooled by isolate into $175 \mathrm{~cm}^{2}$ cell culture flasks and fresh MYB was added. The concentrations of live amoebae in the pooled inocula were measured using a CASY model TT cell counter (Innovatis, Roche Diagnostics) as described by Haugland et al. (2017). Based on the results from the CASY counts, the inocula material was adjusted to the same concentrations for both clonal amoebic strains: 2000 amoebae per litre.

\subsection{Challenge design}

\subsubsection{Fish}

Farmed ballan wrasse with no history of AGD were obtained from a land-based facility near Bergen. The inlet seawater at the ballan wrasse facility was brought from $90 \mathrm{~m}$ depth, particle filtered $(60 \mu \mathrm{m})$ and treated with UV twice. Atlantic salmon (strain Salmobreed) were provided by a commercial producer located in Bergen. At the start of the study, the average weight of the ballan wrasse was $20 \mathrm{~g}$ whereas the average weight of the Atlantic salmon was $80 \mathrm{~g}$. The relative size of wrasse versus salmon follows recommendations for commercial farms (Leclercq et al. 2014, Blanco Gonzalez \& de Boer 2017). The salmon were fully smoltified and ready for seawater transfer when transported to ILAB. All fish were acclimatized to the experimental conditions for $14 \mathrm{~d}$ before the challenge. During this period, the Atlantic salmon were gradually transferred to full sea water. Neither P. perurans nor other Paramoeba spp. were detected in samples from either salmon or wrasse prior to the experiment when examined by real-time RT-PCR ( $\mathrm{n}=15$ per species).

The fish were randomly divided into 4 different groups and placed into 5001 tanks in a flow-through system (water flow $\approx 900 \mathrm{l} \mathrm{h}^{-1}$ tank $^{-1}$ at the start of the experiment). Each tank contained 80 Atlantic salmon and 80 ballan wrasse. The tanks were divided by a grid, so that the 2 species were physically separated but still shared the same water volume - a common garden set-up (Fig. 1). This was done to prevent physical interaction between the wrasse and the salmon. An additional two groups of control fish were placed in separate $150 \mathrm{ltanks}$ (flow $\approx 1250 \mathrm{l} \mathrm{h}^{-1}$ at the start of the experiment), one containing 100 salmon and the other 100 ballan wrasse. The light regime was $12 \mathrm{~h}$ light: $12 \mathrm{~h}$ dark throughout the study and fish were provided feed (Skretting AS) by automated 


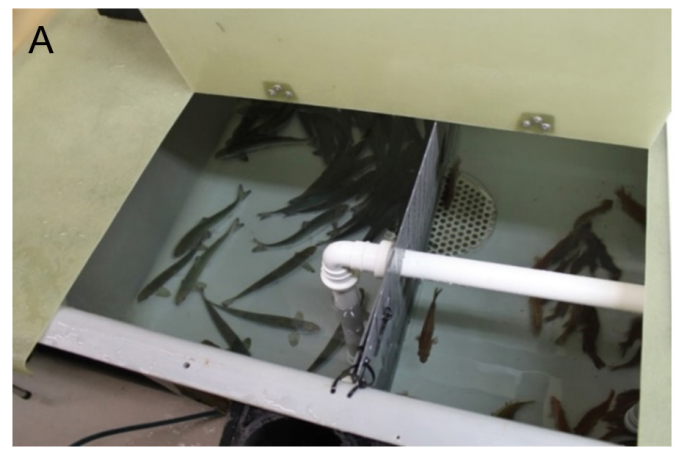

$\mathrm{B}$

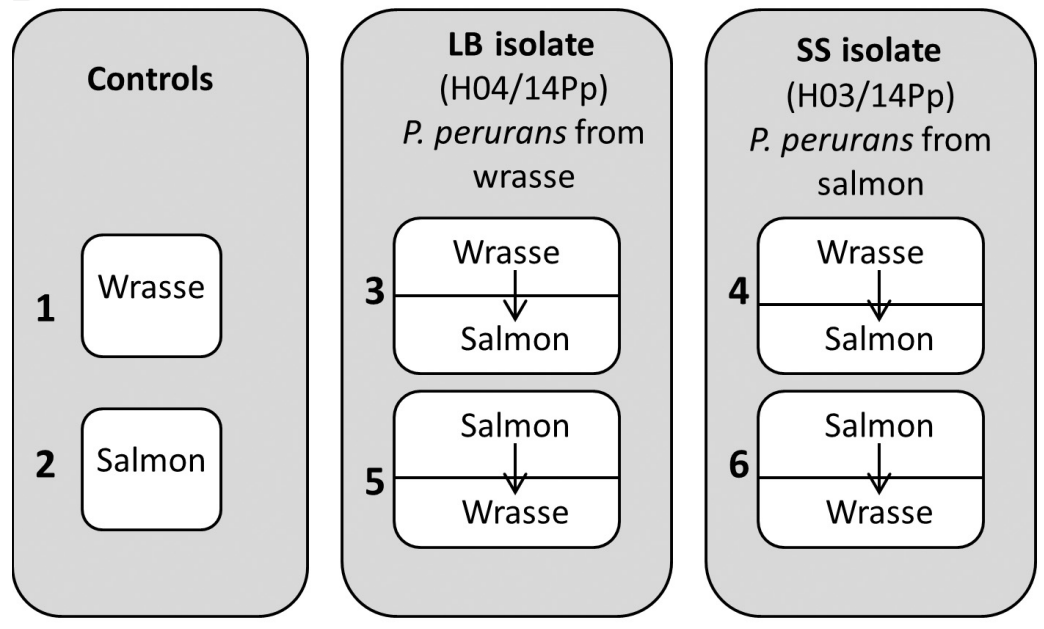

Fig. 1. Experimental set-up. (A) Common garden set up: 5001 tank containing salmon and ballan wrasse divided by a grid. (B) Schematic overview of the tank set-up used in this study. Controls (Groups 1 and 2) were kept in 1501 tanks; Groups 3-6 were kept in 5001 tanks. Groups 3 and 5 were challenged with the 'LB' Paramoeba perurans isolate (H04/14Pp), while Groups 4 and 6 were challenged with the 'SS' isolate (H03/14Pp). In Groups 3 and 4, wrasse were bath-challenged; in Groups 5 and 6, salmon were bath-challenged. Arrows indicate the direction of amoebae shedding

feeders during the $12 \mathrm{~h}$ of light. The water temperature was $15 \pm 0.4^{\circ} \mathrm{C}$. Oxygen saturation was set to $>80 \pm 3 \%$ and salinity was $34 \pm 0.8 \%$. Temperature, oxygen, salinity and water flow, as well as the presence of moribund or dead fish, were examined on a daily basis.

\subsubsection{Bath challenge}

Two groups were challenged with the $P$. perurans isolate from ballan wrasse, LB (H04/14Pp), and 2 groups were challenged with the isolate from Atlantic salmon SS (H03/14Pp). For each isolate, in one group ballan wrasse were bath-challenged and acted as shedders to cohabitating Atlantic salmon, while in the other group, salmon were bath-challenged and acted as shedders to cohabitating ballan wrasse. The
2 remaining groups represented uninfected controls for each fish species (see Fig. 1 for an overview of the experimental groups).

The bath-challenge of the shedder fish was done in 2 separate 1501 tanks containing $120 \mathrm{l}$ of water. Prior to handling, all fish were sedated with isoeugenol (Aqui-S Vet) following the producer's recommendations. All the fish were transferred gently between tanks using a landing net. In one of the tanks, 80 Atlantic salmon and 80 ballan wrasse were challenged with the salmon $P$. perurans isolate (SS), and in another tank 80 salmon and 80 ballan wrasse were challenged with the ballan wrasse $P$. perurans isolate (LB). The final concentration of amoebae in the challenge tanks was $2000 \mathrm{l}^{-1}$. After $1 \mathrm{~h}$ challenge, the water flow (1200 $\left.\mathrm{l} \mathrm{h}^{-1}\right)$ was reinstated for $0.5 \mathrm{~h}$ before the fish were transferred to their respective tanks. Oxygen saturation and fish behaviour was monitored during the entire challenge. The 2 groups of control fish (Groups 1 and 2) were similarly handled, but were exposed to sterile, autoclaved amoeba growth medium (MYB) only. Each of the common garden tanks contained 80 shedders in one of the compartments, and 80 cohabitants were placed in the other compartment after the bath challenge (Groups 3-6). The groups will be referred to as Group 1-6 throughout the paper and an overview of the groups is provided in Fig. 1 and Table 1.

The challenge experiment was approved by the Norwegian Animal Research Authority in 2014 under the identification code 6932 .

\subsection{Sampling and RNA extraction}

Five salmon and 5 ballan wrasse were randomly sampled from each tank weekly. These were euthanized by an overdose (>80-135 $\mathrm{mg} \mathrm{l}^{-1}$ ) of metacain (Finquel $\mathrm{Vet}^{\mathrm{TM}}$ ) and their length and weight were measured. Each individual fish was gill scored from 0 (healthy, no AGD lesions) to 5 (heavily affected by AGD), following a scheme developed for Atlantic salmon (Taylor et al. 2009). After evaluating all 16 gill 
Table 1. Overview of the experimental groups of Atlantic salmon Salmo salar and ballan wrasse Labrus bergylta used in this study. na: not applicable

\begin{tabular}{|lcccccc|}
\hline Group & Infected & $\begin{array}{c}\text { P. perurans } \\
\text { isolate }\end{array}$ & $\begin{array}{c}\text { Origin of } \\
\text { isolate }\end{array}$ & $\begin{array}{c}\text { Bath- } \\
\text { challenged }\end{array}$ & Cohabitants & Brackish water treatment \\
\hline 1 & No & na & na & na & na & na \\
2 & No & na & na & na & na & na \\
3 & Yes & LB (H04/14Pp) & Ballan wrasse & Ballan wrasse & Atlantic salmon & 24 h (both species) \\
4 & Yes & SS (H03/14Pp) & Atlantic salmon & Ballan wrasse & Atlantic salmon & $24 \mathrm{~h}$ (both species) \\
5 & Yes & LB (H04/14Pp) & Ballan wrasse & Atlantic salmon \\
Ballan wrasse & 3 h (both species), 3-5 d (wrasse only) \\
6 & Yes & SS (H03/14Pp) & Atlantic salmon & Atlantic salmon & Ballan wrasse & 3 h (both species), 3-5 d (wrasse only) \\
\hline
\end{tabular}

surfaces, the most affected gill arch was used as the basis for that individual's score, as described in Haugland et al. (2017). Note that this is different from the approach used by Taylor et al. (2009), where AGD-severity is the gross gill score across all 16 hemibranchs.

Gill tissue samples for real-time RT-PCR analyses were taken from the apex of the second gill arch on the left side and deep frozen $\left(-32^{\circ} \mathrm{C}\right)$ until RNA extraction. RNA was extracted from gill tissue and amoeba culture samples using Isol-RNA Lysis Reagent (5 Prime) and a protocol described by Gunnarsson et al. (2017).

For histology, the first gill arch on the right side was sampled and fixed in neutral buffered $10 \%$ formalin (Sigma-Aldrich) for at least $48 \mathrm{~h}$ and kept at $4{ }^{\circ} \mathrm{C}$ until further processing. A selection of affected gill tissues from salmon and ballan wrasse were also fixed in a Karnovsky fixative.

\subsection{Real-time RT-PCR of gill tissue}

An AgPath-ID ${ }^{\mathrm{TM}}$ one-step real-time RT-PCR kit (Applied Biosystems) was used in this study. The real-time RT-PCR was run in a $12.5 \mu$ l volume containing $6.25 \mu \mathrm{l} 2 \times$ RT-PCR buffer, $1.0 \mu \mathrm{l} 10 \mathrm{mM}$ forward primer, $1.0 \mu \mathrm{l} 10 \mathrm{mM}$ reverse primer, $0.22 \mu \mathrm{l}$ $10 \mathrm{mM}$ probe, $0.25 \mu \mathrm{l} 25 \times$ RT-PCR enzyme mix, $1.78 \mu \mathrm{l}$ RNase-free water, and $2.0 \mu \mathrm{l}$ RNA template. The reaction was run using an Applied Biosystems 7500 Real-Time PCR System. The amplification curves were analyzed using Applied Biosystems 7500 Software v.2.3, and the threshold value was fixed at 0.1 . The reaction regime consisted of $45^{\circ} \mathrm{C}$ for $10 \mathrm{~min}$ (reverse transcription); $95^{\circ} \mathrm{C}$ for $10 \mathrm{~min}$ (polymerase activation); and 45 cycles of $95^{\circ} \mathrm{C}$ for $15 \mathrm{~s}$ (DNA-dissociation) and $60^{\circ} \mathrm{C}$ for $45 \mathrm{~s}$ (annealing and elongation). An assay (Pspp) designed to detect $18 \mathrm{~S}$ rRNA of Paramoeba spp. found on fish was used (Pspp-F: 5'-TTG TCA GAG GTG AAA TTC TTG
GAT T-3'; Pspp-probe: 5'-ATG AAA GAC GAA CTT CTG-3'; Pspp-R: 5'-TGA AAA CAT CTT TGG CAA ATG C-3') (Steigen et al. 2018). Since this assay detects several Paramoeba spp., the real-time RT-PCR signals were further verified as $P$. perurans using a specific assay targeting the $18 \mathrm{~S}$ gene of the eukaryotic Perkinsela-like endosymbiont of $P$. perurans (data not shown; PerL-assay, 81 bp PCR product PerL-F: 5'-CAA TGA CAA AGT GAA TGA GTG AAA CC-3'; PerL-R: 5'-CCC AAG CAC GAC ATA GTT TTC TC-3'; PerL probe: 5'-CCT GTC GGG GCA GG-3'). Two assays targeting the elongation factor 1A gene (EF1A) in salmon and ballan wrasse were also used for downstream normalization of the real-time RT-PCR data (Olsvik et al. 2005, Steigen et al. 2018). A standard curve was generated for the Paramoeba spp. assay using a 10 -fold serial dilution of RNA in 3 parallels. Regression analysis was performed, and standard curve slopes ( $s$ ) of Ct versus log quantity RNA, and amplification efficiency $(E$, where $\left.E=\left(10^{1 /-s}\right)-1\right)$ were calculated. The coefficient of determination, $\mathrm{R}^{2}$, was 1.00 for the Paramoeba spp. assay. The slope, $s$, for the Paramoeba spp. assay was -3.47 , and the amplification efficiency, $E$, was 0.94 . For the EF1A assay for wrasse, efficiency was 0.85, whereas efficiency for the EF1A assay for salmon was 1.05. The Ct values and efficiencies from the $2 \mathrm{EF} 1 \mathrm{~A}$ assays were used to calculate the normalized expression of the target (18S rRNA from $P$. perurans) (see Section 2.8). No-template controls and negative RNA-extraction controls were included in each realtime RT-PCR plate set up.

\subsection{Real-time RT-PCR analysis of Paramoeba spp. RNA levels in water}

Water samples ( $1 \mathrm{l})$ were taken from the surface of each tank 1, 4, 6, 11, 13, 18, 20, 25, 27, 32 and 39 days post challenge $(\mathrm{dpc})$. Prior to filtration, $15 \mu \mathrm{l}$ sterile filtered supernatant of viral haemorrhagic septicae- 
mia virus (VHSV) grown in RTgill-W1 cells was added to each sample as a filtration control. The sample was filtered through using electropositive filters (Zeta Plus ${ }^{\mathrm{TM}}$ 1MDS Virosorb, 3M Purification) as described by Andersen et al. (2010) using a VP 100C vacuum pump (VWR $\left.{ }^{\circledR}\right)$. After filtration, the filters were placed in small petri dishes with $1.4 \mathrm{ml}$ lysis buffer (E.Z.N.A Total RNA Extraction kit, Omega Bio-Tek) containing $28 \mu \mathrm{l}$ of $\beta$-mercaptoethanol for 10 min with gentle shaking (Andersen et al. 2010). Lysis buffer $(0.7 \mathrm{ml})$ was then transferred to two $1.5 \mathrm{ml}$ Eppendorf tubes ( $350 \mathrm{ml}$ in each), and stored at $-32^{\circ} \mathrm{C}$. Prior to RNA extraction, $7 \mu \mathrm{l}$ of salmonid alphavirus (SAV, sterile filtered supernatant of SAV grown in Chinook salmon embryo [CHSE-214] cells) was added to each sample, as an RNA extraction control. RNA was extracted from the sample using the E.Z.N.A Total RNA Kit following the manufacturer's instructions. Samples were analysed using assays for Paramoeba spp., VHSV and SAV in a 7500 real-time PCR System (Hodneland \& Endresen 2006, Duesund et al. 2010). All Ct values obtained for the Pspp-assay were normalized against $\mathrm{Ct}$ values obtained for the 2 exogenous controls (SAV and VHSV).

\subsection{Normalization of real-time RT-PCR data}

Normalized expression (NE) was calculated using the formula NE $=\left(E_{\text {ref }}\right)^{\mathrm{Ct} \mathrm{ref}} /\left(E_{\text {target }}\right)^{\mathrm{Ct} \text { target }}$ (Simon 2003). All normalized expression values were transformed into NE-folds and $\log _{2}$-transformed as described by Andersen et al. (2010). Figures were drawn using GraphPad Prism version 6.0 for Windows (GraphPad Software).

\subsection{PCR and sequencing}

PCR and sequencing were performed to confirm the identity of clonal isolates as $P$. perurans, and to confirm all re-isolations performed during the challenge test as $P$. perurans. RNA used for sequencing was extracted from amoeba cultures using the E.Z.N.A. tissue kit ${ }^{\mathrm{TM}}$ (Omega Bio-Tek) and cDNA made through a reverse transcriptase reaction with GeneAmp ${ }^{\text {TM }}$ PCR system 2700 (Applied Biosystems). PCR was performed using diagnostic 18S primers for P. perurans (Young et al. 2008). The reaction mix contained $2 \mu \mathrm{l}$ cDNA, $2.5 \mu \mathrm{l} 10 \times$ Extra buffer (VWR ${ }^{\circledR}$ ), $1.25 \mathrm{mM}$ dNTPs, $0.15 \mu \mathrm{l}$ (0.75 units) Taq DNA polymerase $\left(\mathrm{VWR}^{\circledR}\right), 1.0 \mu \mathrm{l}(5.0 \mu \mathrm{M})$ of forward and reverse primer and $16.85 \mu \mathrm{l}$ nuclease-free water for a final volume of $25 \mu \mathrm{l}$. Amplification was performed in a GeneAmp PCR system 2700 (Applied Biosystems). The reaction regime consisted of $5 \mathrm{~min}$ at $94^{\circ} \mathrm{C}_{i} 35$ cycles at $94^{\circ} \mathrm{C}$ for $30 \mathrm{~s}, 15 \mathrm{~s}$ at $55^{\circ} \mathrm{C}$, and $2 \mathrm{~min}$ at $72^{\circ} \mathrm{C}$; followed by an additional $5 \mathrm{~min}$ at $72^{\circ} \mathrm{C}$ and $4^{\circ} \mathrm{C}$ hold. The PCR products were visualised using agarose gel electrophoresis and purified with ExoSAP-IT (USB ${ }^{\circledR}$ ). Sequencing was done using a BigDye $^{\mathrm{TM}}$ v3.1 terminator cycle sequencing reaction kit (Applied Biosystems) at the sequencing facility at the University of Bergen (www.seqlab.uib.no). Sequences were assembled using VectorNTI software (Invitrogen). GenBank searches were done with BLAST (2.0).

\subsection{Histology}

Pathological gill changes due to P. perurans infection were examined at $28 \mathrm{dpc}$. Formalin-fixed gills were embedded in paraffin and sectioned $(2-3 \mu \mathrm{m})$ according to standard procedures (Culling et al. 1985). Additional samples were taken from cases with significant gill changes (white patches). These additional samples were fixed in a modified Karnovsky solution, where $4 \%$ sucrose was added and distilled water was replaced by a Ringer's solution (Steigen et al. 2013). These samples were stored at $4^{\circ} \mathrm{C}$ and subsequently embedded in EMbed 812 following standard procedures.

\subsection{Re-isolation of amoebae}

Re-isolation of the amoebae on MYA was attempted from the gills of one individual from both the shedder and cohabitant species in each tank at 21 and $28 \mathrm{dpc}$. Gill tissue and mucus were scraped off gills with a scalpel, and the plates were incubated at $16^{\circ} \mathrm{C}$ with a seawater overlay. After $1 \mathrm{wk}, 200 \mu \mathrm{l}$ of amoeba-containing supernatant from the plates was transferred to an Eppendorf tube and $500 \mu \mathrm{l}$ RNAlater ${ }^{\circledR}$ (LifeTechnologies) was added to the sample prior to storage at $-32^{\circ} \mathrm{C}$ until analysis.

\subsection{Treatment of $P$. perurans infection and AGD using brackish water}

After the challenge study was completed (32 dpc), the remaining fish in the challenged groups were treated using brackish water. The salinity was lowered to $<15 \%$ o $(14.5 \pm 0.5 \%)$ in all tanks. Groups 3 and 4 received brackish seawater for $24 \mathrm{~h}$, whereas 
Groups 5 and 6 received brackish seawater for $3 \mathrm{~h}$ (short treatment group; see Table 1). Full seawater (34\%) was reinstated after the treatment period. Gill samples were taken from 15 fish of each species in each group after each treatment to test for presence of $P$. perurans (RT-PCR analyses). In addition, samples were collected from 15 individuals from both Groups 3 and 4, $7 \mathrm{~d}$ after the $24 \mathrm{~h}$ treatment. Re-isolation of amoebae was also attempted from fish sampled directly after treatment, and $7 \mathrm{~d}$ post treatment, by pooling gill tissue from 5 individuals from each species in each group ( $\mathrm{n}=15$ fish per group) on MYA. Water samples (1 l) were collected at 0.5, 1.5, 3, 4, 5, $6,12,24$ and $27 \mathrm{~h}$ after the start of the $24 \mathrm{~h}$ brackish water treatment from the tanks containing Groups 3 and 4. The water samples were filtered and processed as described by Andersen et al. (2010).

At 35 dpc the salmon in Groups 5 and 6 were euthanized due to severe AGD in Group 5. The salmon in the other challenged tanks (Groups 3 and 4) and the salmon controls (Group 2) were terminated at $41 \mathrm{dpc}$. An additional treatment with brackish water was initiated in challenge Groups 5 and 6 for the wrasse only (see Table 1). The ballan wrasse in these groups ( $\mathrm{n}=10$ fish per tank) were treated again $4 \mathrm{~d}$ after the first short treatment, this time for $5 \mathrm{~d}$, with sampling performed on Days 3, 4 and 5. MYA culturing for amoebae was also carried out by pooling gill tissue from 5 individuals of each group $(n=10)$ on MYA plates.

\subsection{Statistical analysis}

Statistical analyses were performed to examine temporal changes in $P$. perurans density within the groups, using NE, a measure of the amount of amoeba ribosomal RNA, as a proxy for amoeba density (see Section 2.8). Density in negative samples was set at 0 . Since the data was non-normal and variance often unequal, non-parametric statistical analyses were used. The Mann-Whitney $U$ test (MW) was used to compare 2 samples and the Kruskal-Wallis test (KW) was used to compare $>2$ samples. Fisher's exact test (FET) was used to compare prevalences between samples. Results were considered significant if $p$-values were $<0.05$. Statistical analyses were conducted using Statistica 12 software (StatSoft). Different EF1A assays were used for the 2 fish species, so NE values may not be directly comparable. Therefore, the $P$. perurans levels in salmon and ballan wrasse gill tissue were compared using Ct values only. These were expressed as 'load', representing the number of cycles run (45) subtracting $\mathrm{Ct}$ values. $\mathrm{Ct}$ of negative samples was set at 45 , giving a load of 0 .

\section{RESULTS}

\subsection{Gill lesion scores}

Gross gill lesions were seen throughout the study to a varying degree in all fish groups challenged with Paramoeba perurans. The lesions were white, mucoid spots or patches unevenly distributed across the gill surfaces. The patches in ballan wrasse were paler, smaller, less mucoid and less protrudent than those in salmon. No lesions were seen in the control groups.

A temporal increase in the mean gill score values of salmon and wrasse exposed to the LB isolate (Groups 3 and 5) could be seen for both bath-challenged individuals and cohabitants (Table 2). Where the SS isolate was used (Groups 4 and 6), gill scores clearly increased for salmon as shedders (Group 6) or as cohabitants (Group 4). Conversely, in wrasse exposed to the SS isolate, average gill score peaked at 0.8 at $14 \mathrm{dpc}$ (as shedders) and $21 \mathrm{dpc}$ (cohabitants) before declining. The highest mean gill scores could be seen in fish from the tanks that had been challenged with the LB isolate (Groups 3 and 5) (Table 2). For all $P$. perurans-challenged groups, independent of isolate, salmon had the highest gill scores and score prevalence, though average gill score was more advanced in shedder salmon than cohabitant salmon. The gill scores also indicated faster AGD development in salmon than wrasse, independent of $P$. perurans isolate. The scores of salmon cohabitating with bath-challenged wrasse quickly surpassed the scores of the shedder wrasse.

Also independent of $P$. perurans isolate, gill scores increased more rapidly when salmon acted as shedders (Groups 5 and 6) than when wrasse acted as shedders (Groups 3 and 4) (Table 2). At $14 \mathrm{dpc}$, gill scores $>0$ were registered in shedders from all infected groups. In Groups 5 and 6, all (10/10) bath-challenged salmon sampled had gill scores $>0$, compared to $4 / 10$ (FET, p = 0.01) of the ballan wrasse in Groups 3 and 4. Gill changes were not registered in any cohabitants in any groups until $21 \mathrm{dpc}_{\text {, but at }}$ $21 \mathrm{dpc}$ and $28 \mathrm{dpc}$, gill scores $>0$ were seen in both bath-challenged and cohabitant individuals in all groups. The number of PCR positive fish with a gill score of 0 was higher for ballan wrasse than salmon (Table 3). Only 2 salmon were PCR positive without any macroscopic gill lesions, i.e. with a gill score of 0 (4.2\% of all PCR positive salmon), while 23 PCR pos- 
Table 2. Individual and mean gill scores for 5 fish from each of the 6 study groups at each sample point throughout the experiment, prior to treatment. Groups 1 and 2 were uninfected control groups, whereas Groups 3-6 were challenged with P. perurans. Groups 3 and 5 were challenged with P. perurans isolate 'LB' (H04/14Pp) from ballan wrasse, whereas Groups 4 and 6 were challenged with $P$. perurans isolate 'SS' (H03/14Pp) from Atlantic salmon. BW: Ballan wrasse; AS: Atlantic salmon; mean GS: mean gill score; $\mathrm{n}$ GS: number of fish with gill score $>0$; dpc: days post challenge

\begin{tabular}{|c|c|c|c|c|c|c|c|c|c|c|}
\hline \multirow[t]{2}{*}{ Dpc } & \multirow{2}{*}{$\begin{array}{c}\text { Group } 1 \\
\text { Mock } \\
\text { BW }\end{array}$} & \multirow{2}{*}{$\begin{array}{c}\text { Group } 2 \\
\text { Mock } \\
\text { AS }\end{array}$} & \multicolumn{2}{|c|}{$\begin{array}{c}\text { Group } 3- \\
\text { LB isolate }\end{array}$} & \multicolumn{2}{|c|}{$\begin{array}{c}\text { Group } 4- \\
\text { SS isolate }\end{array}$} & \multicolumn{2}{|c|}{$\begin{array}{c}\text { Group } 5- \\
\text { LB isolate }\end{array}$} & \multicolumn{2}{|c|}{$\begin{array}{c}\text { Group } 6- \\
\text { SS isolate }\end{array}$} \\
\hline & & & $\begin{array}{l}\text { Shedder } \\
\text { (BW) }\end{array}$ & $\begin{array}{c}\text { Cohab } \\
\text { (AS) }\end{array}$ & $\begin{array}{c}\text { Shedder } \\
\text { (BW) }\end{array}$ & $\begin{array}{l}\text { Cohab } \\
\text { (AS) }\end{array}$ & $\begin{array}{l}\text { Shedder } \\
\text { (AS) }\end{array}$ & $\begin{array}{l}\text { Cohab } \\
\text { (BW) }\end{array}$ & $\begin{array}{l}\text { Shedder } \\
\text { (AS) }\end{array}$ & $\begin{array}{l}\text { Cohab } \\
\text { (BW) }\end{array}$ \\
\hline \multirow[t]{5}{*}{7} & 0 & 0 & 0 & 0 & 0 & 0 & 1 & 0 & 0 & 0 \\
\hline & 0 & 0 & 0 & 0 & 0 & 0 & 0 & 0 & 1 & 0 \\
\hline & 0 & 0 & 0 & 0 & 0 & 0 & 1 & 0 & 1 & 0 \\
\hline & 0 & 0 & 0 & 0 & 0 & 0 & 1 & 0 & 1 & 0 \\
\hline & 0 & 0 & 0 & 0 & 0 & 0 & 2 & 0 & 1 & 0 \\
\hline $\begin{array}{l}\text { Mean GS } \\
\text { (n GS) } 7 \text { dpc }\end{array}$ & $0(0)$ & $0(0)$ & $0(0)$ & $0(0)$ & $0(0)$ & $0(0)$ & $1(4)$ & $0(0)$ & $0.8(4)$ & $0(0)$ \\
\hline \multirow[t]{5}{*}{14} & 0 & 0 & 0 & 0 & 1 & 0 & 3 & 0 & 2 & 0 \\
\hline & 0 & 0 & 0 & 0 & 0 & 0 & 3 & 0 & 2 & 0 \\
\hline & 0 & 0 & 0 & 0 & 2 & 0 & 2 & 0 & 1 & 0 \\
\hline & 0 & 0 & 1 & 0 & 0 & 0 & 3 & 0 & 1 & 0 \\
\hline & 0 & 0 & 0 & 0 & 1 & 0 & 3 & 0 & 1 & 0 \\
\hline $\begin{array}{l}\text { Mean GS } \\
\text { (n GS) } 14 \mathrm{dpc}\end{array}$ & $0(0)$ & $0(0)$ & $0.2(1)$ & $0(0)$ & $0.8(3)$ & $0(0)$ & $2.8(5)$ & $0(0)$ & $1.4(5)$ & $0(0)$ \\
\hline \multirow[t]{5}{*}{21} & 0 & 0 & 0 & 2 & 0 & 0 & 4 & 3 & 2 & 1 \\
\hline & 0 & 0 & 1 & 1 & 0 & 1 & 5 & 1 & 1 & 0 \\
\hline & 0 & 0 & 1 & 1 & 0 & 1 & 4 & 2 & 2 & 1 \\
\hline & 0 & 0 & 1 & 2 & 1 & 0 & 3 & 3 & 2 & 1 \\
\hline & 0 & 0 & 0 & 2 & 0 & 1 & 4 & 1 & 1 & 1 \\
\hline $\begin{array}{l}\text { Mean GS } \\
\text { (n GS) } 21 \mathrm{dpc}\end{array}$ & $0(0)$ & $0(0)$ & $0.6(3)$ & $1.6(5)$ & $0.2(1)$ & $0.6(3)$ & $4(5)$ & $2(5)$ & $1.6(5)$ & $0.8(5)$ \\
\hline \multirow[t]{5}{*}{28} & 0 & 0 & 2 & 4 & 0 & 1 & 5 & 3 & 3 & 0 \\
\hline & 0 & 0 & 2 & 3 & 0 & 0 & 4 & 2 & 3 & 0 \\
\hline & 0 & 0 & 2 & 4 & 1 & 1 & 5 & 1 & 2 & 1 \\
\hline & 0 & 0 & 2 & 4 & 0 & 2 & 5 & 4 & 2 & 0 \\
\hline & 0 & 0 & 2 & 3 & 0 & 2 & 5 & 1 & 2 & 0 \\
\hline $\begin{array}{l}\text { Mean GS } \\
\text { (n GS) } 28 \mathrm{dpc}\end{array}$ & $0(0)$ & $0(0)$ & $2(5)$ & $3.6(5)$ & $0.2(1)$ & $1.2(4)$ & $4.8(5)$ & $2.2(5)$ & $2.4(5)$ & $0.2(1)$ \\
\hline
\end{tabular}

itive wrasse $(48.9 \%$ of all PCR positive wrasse) had no grossly observable gill pathology (Table 3 ). More PCR positive wrasse had low gill scores than PCR positive salmon. Higher gill scores were mostly seen for salmon, where $43.8 \%$ of real-time RT-PCR positive individuals had gill scores $\geq 3$. Conversely, only $8.5 \%$ of real-time RT-PCR positive wrasse had gill scores 3 or above.

\subsection{Real-time RT-PCR analysis of $P$. perurans levels in gill tissue}

The highest densities of $P$. perurans rRNA were observed in salmon from Group 5 that had been challenged with the $P$. perurans isolate $\mathrm{LB}$, sampled at $28 \mathrm{dpc}(\mathrm{KW}, \mathrm{df}=3, \mathrm{p}<0.05$; Fig. 2). At $14 \mathrm{dpc}$ in
Group 6, $21 \mathrm{dpc}$ in Group 5 and $28 \mathrm{dpc}$ in Group 3, the $P$. perurans rRNA levels in some cohabitant individuals exceeded the levels found in some shedders (Fig. 2). In the tanks where wrasse had acted as shedders (Groups 3 and 4), no cohabitating salmon tested positive for the amoebae using real-time RT-PCR until $21 \mathrm{dpc}$, independent of the isolate used (Fig. 2). In the groups where salmon had acted as shedders (Groups 5 and 6), amoeba RNA could be detected in the gills of the wrasse cohabitants by $14 \mathrm{dpc}$. A reduction in P. perurans RNA levels was seen in wrasse gills from 7 to $14 \mathrm{dpc}$ in Groups 3 and 4 where wrasse were shedders, before the levels increased on Days 21 and 28. In Groups 5 and 6, however, amoeba density increased steadily throughout the study.

A significant difference in the densities of the $2 P$. perurans isolates could be seen between Groups 5 
Table 3. Summary of gill scores for all challenged fish in the study from 7 to $28 \mathrm{dpc}$. The number of PCR positive and PCR negative fish for each gill score is shown for both species

\begin{tabular}{|c|c|c|c|c|c|c|c|c|}
\hline \multirow[t]{2}{*}{ Score } & \multirow{2}{*}{ Total } & \multicolumn{3}{|c|}{ Atlantic salmon - } & \multicolumn{4}{|c|}{-Ballan wrasse } \\
\hline & & $\begin{array}{l}\text { PCR } \\
+ \text { ve }\end{array}$ & $\begin{array}{l}\text { PCR } \\
\text {-ve }\end{array}$ & $\begin{array}{c}\% \text { PCR } \\
\text { +ve }\end{array}$ & Total & $\begin{array}{l}\text { PCR } \\
+ \text { ve }\end{array}$ & $\begin{array}{l}\text { PCR } \\
\text {-ve }\end{array}$ & $\begin{array}{c}\% \text { PCR } \\
\text { +ve }\end{array}$ \\
\hline 0 & 25 & 2 & 23 & 8.0 & 51 & 23 & 28 & 45.1 \\
\hline 1 & 19 & 12 & 7 & 63.2 & 17 & 12 & 5 & 70.6 \\
\hline 2 & 15 & 13 & 2 & 86.7 & 8 & 8 & 0 & 100.0 \\
\hline 3 & 9 & 9 & 0 & 100.0 & 3 & 3 & 0 & 100.0 \\
\hline 4 & 7 & 7 & 0 & 100.0 & 1 & 1 & 0 & 100.0 \\
\hline 5 & 5 & 5 & 0 & 100.0 & 0 & 0 & 0 & 0.0 \\
\hline Sum & 80 & 48 & 32 & 60.0 & 80 & 47 & 33 & 58.8 \\
\hline
\end{tabular}

and 6, where Atlantic salmon were bath-challenged, from 14 dpc onwards (MW, p < 0.02). The highest densities were seen in salmon exposed to $P$. perurans LB (Group 5). No differences in amoeba densities were detected in wrasse receiving heterologous challenges (Groups 3 and 4).

A significant temporal increase in amoeba densities was seen in salmon and wrasse shedders after being challenged with $P$. perurans LB (Groups 3 and 5; KW, df $=3, \mathrm{p}<0.001, \mathrm{p}<0.02$ respectively), and in salmon $(p<0.01)$ but not wrasse challenged with the SS isolate (Groups 4 and 6; KW, df = 3). Load was significantly higher in salmon shedders in Group 5 than wrasse shedders in Group 3 from $14 \mathrm{dpc}$ onward (MW, p < 0.03). In Groups 4 and 6, challenged with isolate $\mathrm{SS}$, lower amoeba densities were seen than in Groups 3 and 5, although some individuals showed loads similar to individuals in Group 3 and 5. Amoeba densities were not significantly different between the 2 fish species in Groups 4 and 6 (MW, p = 0.06).

\subsection{Real-time RT-PCR analysis of Paramoeba RNA levels in water}

Real-time RT-PCR analysis of water samples showed a temporal increase in the amoeba RNA levels during the challenge study in the $P$. perurans challenged Groups 3, 5 and 6, with highest levels towards the end of the study, at $27 \mathrm{dpc}$ in Group 5 (Table 4). In the tank where wrasse had been bath-
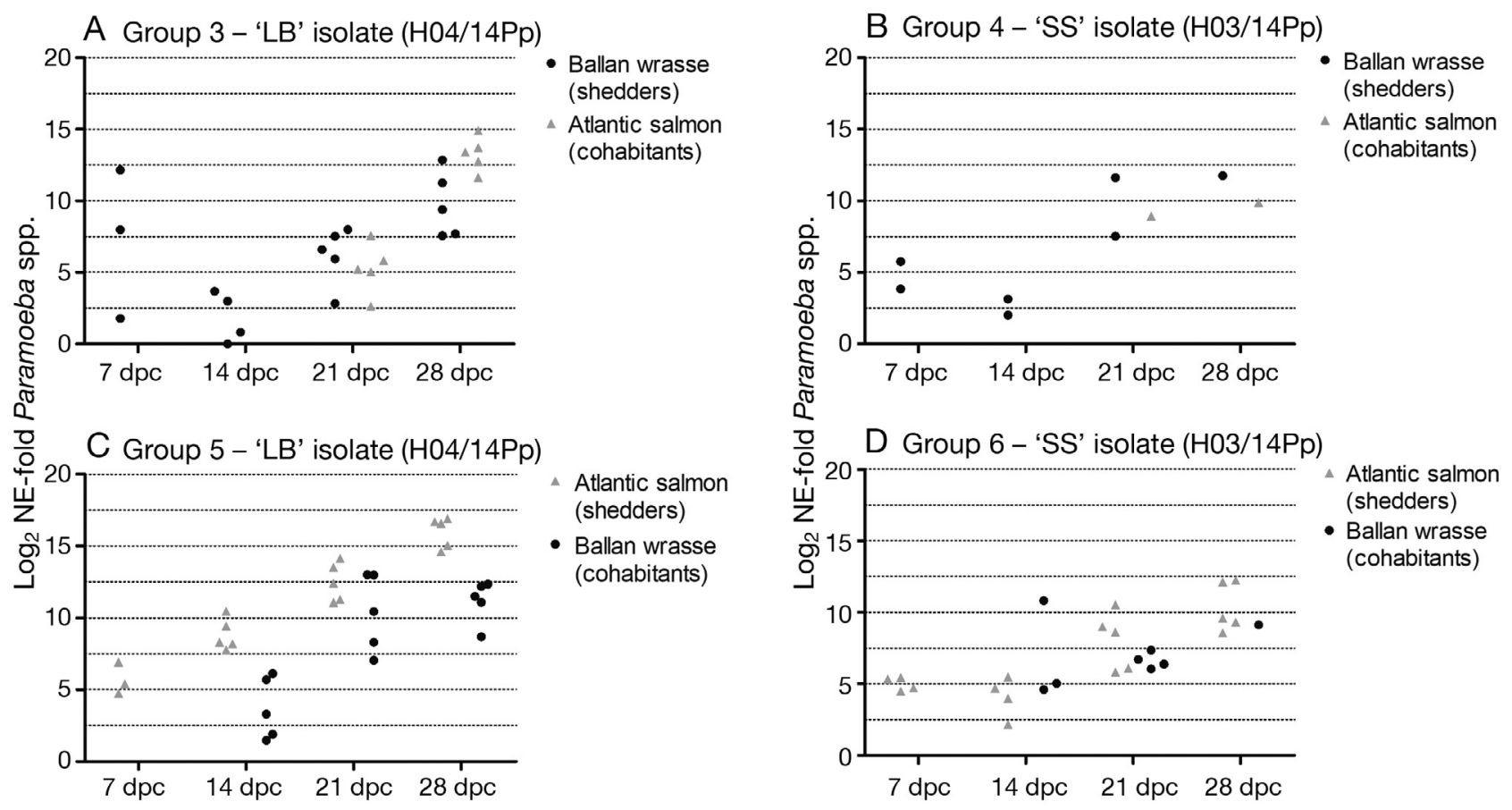

Fig. 2. P. perurans RNA levels in gills. Ct values from real-time RT-PCR analysis were normalized against EF1A for each host species (normalized expression, NE), transformed into fold increase and $\log _{2}$-transformed for the final presentation. (A) Group 3 and (C) Group 5 were challenged with the $P$. perurans isolate 'LB' (H04/14Pp), while (B) Group 4 and (D) Group 6 were challenged with the $P$. perurans isolate 'SS' (H03/14Pp). $\mathrm{N}=5$ of each species on each sampling day. Different EF1A assays were used for the 2 fish species 
Table 4. Real-time RT-PCR analysis of Paramoeba spp. RNA levels in water during the experiment, normalized against exogenous controls VHSV and SAV. The table shows $\log _{2}$-transformed normalized expression (NE) values (relative to the lowest NE value for water samples, which was seen $6 \mathrm{dpc}$ in Group 6). The first treatments were initiated at $32 \mathrm{dpc}$, and salmon in Groups 5 and 6 were terminated at 35 dpc. nd: Paramoeba spp. RNA not detected

\begin{tabular}{|c|c|c|c|c|c|c|c|c|}
\hline \multirow[t]{2}{*}{$\mathrm{Dpc}$} & \multicolumn{2}{|c|}{$\begin{array}{c}\text { Group } 3 \text { (LB isolate) } \\
\text { Paramoeba spp. RNA levels }\end{array}$} & \multicolumn{2}{|c|}{$\begin{array}{c}\text { Group } 4 \text { (SS isolate) } \\
\text { Paramoeba spp. RNA levels }\end{array}$} & \multicolumn{2}{|c|}{$\begin{array}{c}\text { Group } 5 \text { (LB isolate) } \\
\text { Paramoeba spp. RNA levels }\end{array}$} & \multicolumn{2}{|c|}{$\begin{array}{c}\text { Group } 6 \text { (SS isolate) } \\
\text { Paramoeba spp. RNA levels }\end{array}$} \\
\hline & vs. VHSV & vs. SAV & vs. VHSV & vs. SAV & vs. VHSV & vs. SAV & vs. VHSV & vs. SAV \\
\hline 1 & nd & nd & nd & nd & nd & nd & nd & nd \\
\hline 4 & nd & nd & nd & nd & nd & nd & nd & nd \\
\hline 6 & nd & nd & nd & nd & nd & nd & 1.00 & 1.00 \\
\hline 11 & nd & nd & nd & nd & 3.01 & 2.87 & 1.98 & 1.78 \\
\hline 13 & nd & nd & nd & nd & nd & nd & nd & nd \\
\hline 18 & nd & nd & nd & nd & 6.40 & 4.26 & 6.30 & 4.73 \\
\hline 20 & nd & nd & nd & nd & 5.18 & 4.35 & 3.70 & 2.99 \\
\hline 25 & 2.98 & 3.74 & nd & nd & 6.39 & 6.46 & 3.55 & 3.74 \\
\hline 27 & 3.83 & 4.27 & nd & nd & 7.49 & 7.16 & 4.36 & 4.35 \\
\hline 32 & 6.66 & 4.86 & nd & nd & 9.09 & 7.21 & nd & nd \\
\hline 39 & nd & nd & nd & nd & nd & nd & nd & nd \\
\hline
\end{tabular}

challenged with the LB isolate (Group 3), water samples were positive at 25 and $27 \mathrm{dpc}$ only. In the groups where salmon had been bath-challenged, independent of which $P$. perurans isolate was used, amoeba RNA was detected in the water earlier. In Group 6, where salmon had been challenged with the SS isolate, water was positive from $6 \mathrm{dpc}$ onward, while in Group 5, where salmon had been challenged with the LB isolate, water sampled from $11 \mathrm{dpc}$ onward was positive. However, an exception to the observed patterns was the samples from $13 \mathrm{dpc}$ which were negative in all groups. Paramoeba spp. RNA was not detected in water from the group where wrasse had been bath-challenged with the SS isolate (Group 4) or from any of the control groups.

\subsection{Re-isolation of amoebae}

$P$. perurans were re-isolated from both shedders and cohabitants in both of the tanks challenged with LB (Groups 3 and 5) at $21 \mathrm{dpc}$. When wrasse were challenged with SS (Group 4), amoebae were re-isolated from both wrasse and salmon at $21 \mathrm{dpc}$. In Group 6 where salmon were exposed to SS, no amoebae were re-isolated from either species at $21 \mathrm{dpc}$.

At $28 \mathrm{dpc}$, amoebae could be re-isolated from both shedders and cohabitants in all tanks. All amoebae that were isolated on MYA from the gills of the fish in the experiments showed $100 \%$ identity to $P$. perurans (520 bp 18S rRNA gene sequences). No amoebae were isolated from fish in the control tanks (Groups 1 and 2).

\subsection{Histology}

Histologic examination of gill samples revealed extensive multifocal hyperplasia, hypertrophy and an increase in the number of mucus cells (Fig. 3) in both salmon and wrasse. Amoebae were often observed in close proximity to the outer epithelial layer and sometimes in lacunae. The gill lesions seen in Atlantic salmon were more extensive than the gill lesions in ballan wrasse. Samples embedded in Embed 812 revealed similar pathology to that seen in the paraffin embedded samples. In areas with amoebae, a massive vacuolization of the gill epithelium was evident (Fig. 4).

\subsection{Mortality}

Mortality was only seen in Group 5, where Atlantic salmon had been challenged with the $P$. perurans isolate LB (H04/14Pp) originating from wrasse. In this group, 3 wrasse died 23-31 d after exposure and 35 salmon in the period after $27 \mathrm{~d}$ of exposure. Real-time RT-PCR analysis of gill tissue showed high levels of $P$. perurans RNA in dead fish. Due to the severity of AGD, the remaining salmon $(n=10)$ in the tank where mortality had occurred were euthanized at $35 \mathrm{dpc}$. Mortality was not observed in the tanks where fish had been bath-challenged with the SS isolate (H03/14Pp) from salmon or in the uninfected Atlantic salmon controls during the experiment (Group 2). In the control tank with naïve wrasse (Group 1), 3 individuals died shortly after arrival, but $P$. perurans RNA could not be detected in these individuals. 
A

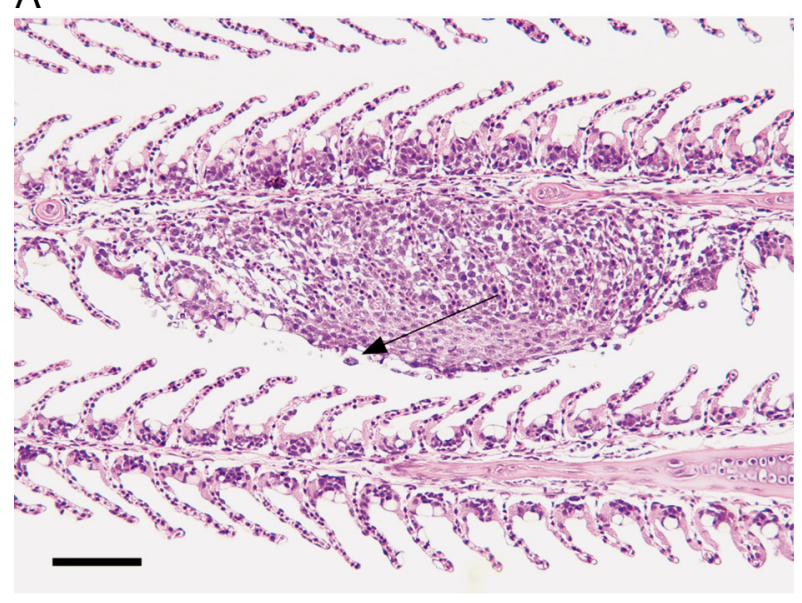

C

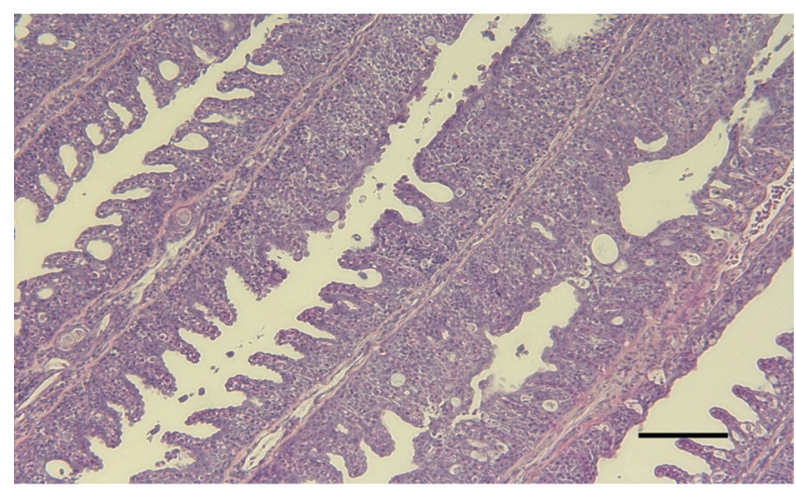

B

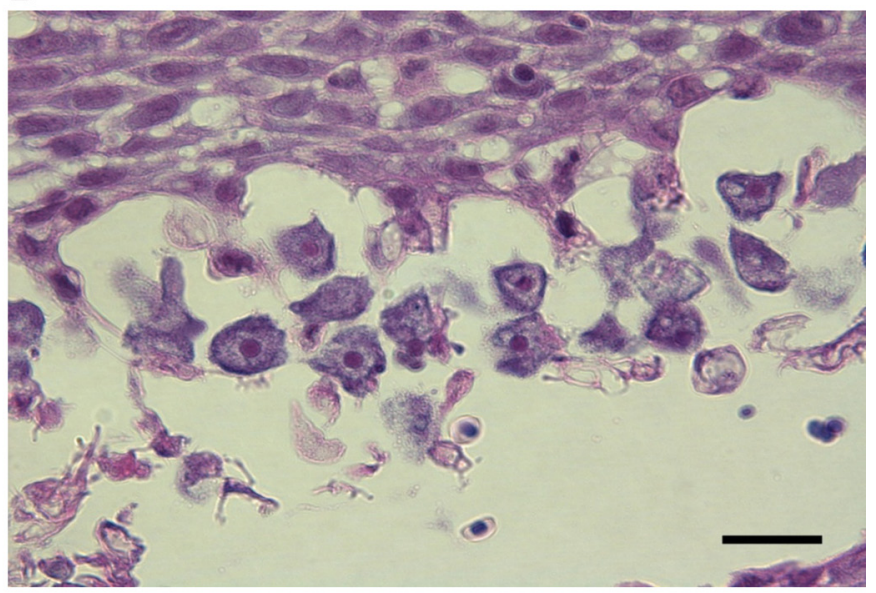

$\mathrm{D}$

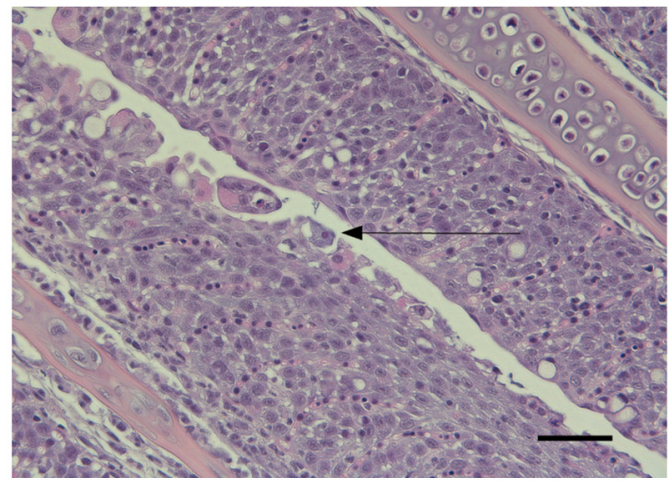

Fig. 3. Histological gill lesions. (A) Atlantic salmon (shedder) from Group 5, 'LB' (H04/14Pp) isolate, sampled at 28 dpc. Lesions with massive hypertrophy and hyperplasia in parts of the gill filament may be seen. The arrow shows amoebae in close proximity to the affected epithelium. Scale bar $=200 \mu \mathrm{m}$. (B) Atlantic salmon (shedder) from Group 5, 'LB' (H04/14Pp) isolate, sampled at 28 dpc. Amoebae were often seen in large quantities close to the gill epithelium. Scale bar $=20 \mu \mathrm{m}$. (C) Ballan wrasse (shedder) from Group 3, 'LB' (H04/14Pp) isolate, sampled at 28 dpc. Hypertrophy and hyperplasia, causing fusion of secondary lamellae, may be seen. A number of interlamellar lacunae containing amoebae are visible. Scale bar = $100 \mu \mathrm{m}$. (D) Atlantic salmon (shedder) from Group 5, 'LB' (H04/14Pp) isolate, sampled at $28 \mathrm{dpc}$. Significant hypertrophy and hyperplasia causing fusion of secondary lamellae are visible. The arrow shows amoebae in close proximity or attached to the gill epithelium. Scale bar $=50 \mu \mathrm{m}$

\subsection{Treatment using brackish water}

\subsubsection{Short treatments ( $3 \mathrm{~h}$ and $24 \mathrm{~h})$ : salmon and wrasse}

During treatment with brackish water, the salinity was lowered from $34 \pm 0.8 \%$ to $14.5 \pm 0.5 \%$ in all challenge groups. Groups 3 and 4 were treated for $24 \mathrm{~h}$ with brackish water, $32 \mathrm{dpc}$ (see Table 1). At the time of treatment, $100 \%$ of salmon and wrasse in Group 3 and $20 \%$ of salmon and wrasse in Group 4 tested positive for $P$. perurans using real-time RT-PCR (Fig. 5). The salmon had a mean gill score of 3.6 (range 3-4) in Group 3, whereas the wrasse in the same group all had a gill score of 2 . In Group 4, the salmon had a mean gill score of 1.2 (range $0-2$ ), while the wrasse had a mean gill score of 0.2 (range $0-1$ ). After $24 \mathrm{~h}$ of treatment, a decrease in the prevalence of real-time RT-PCR positive samples could be seen for wrasse (5/15, FET, p < 0.05) but not for salmon (12/15, FET, $\mathrm{ns}$ ) in Group 3, and no positive samples (0/6 for salmon and wrasse) could be detected in Group 4. Seven $\mathrm{d}$ after the $24 \mathrm{~h}$ treatment, the prevalence of real-time RT-PCR positives in Group 3 were significantly lower for both wrasse $(1 / 15, F E T, p<0.001)$ and salmon $(8 / 15, F E T, p<0.05)$ relative to the prevalence prior to treatment. A single positive shedder was seen in Group 4 at this time (Fig. 5). The water samples from Group 3 during treatment were positive at all time points from $0.5-12 \mathrm{~h}$, but negative at $24-27 \mathrm{~h}$ (Table 5). Amoebae were not detected in the water from Group 4. No viable amoebae from Group 3 or 4 


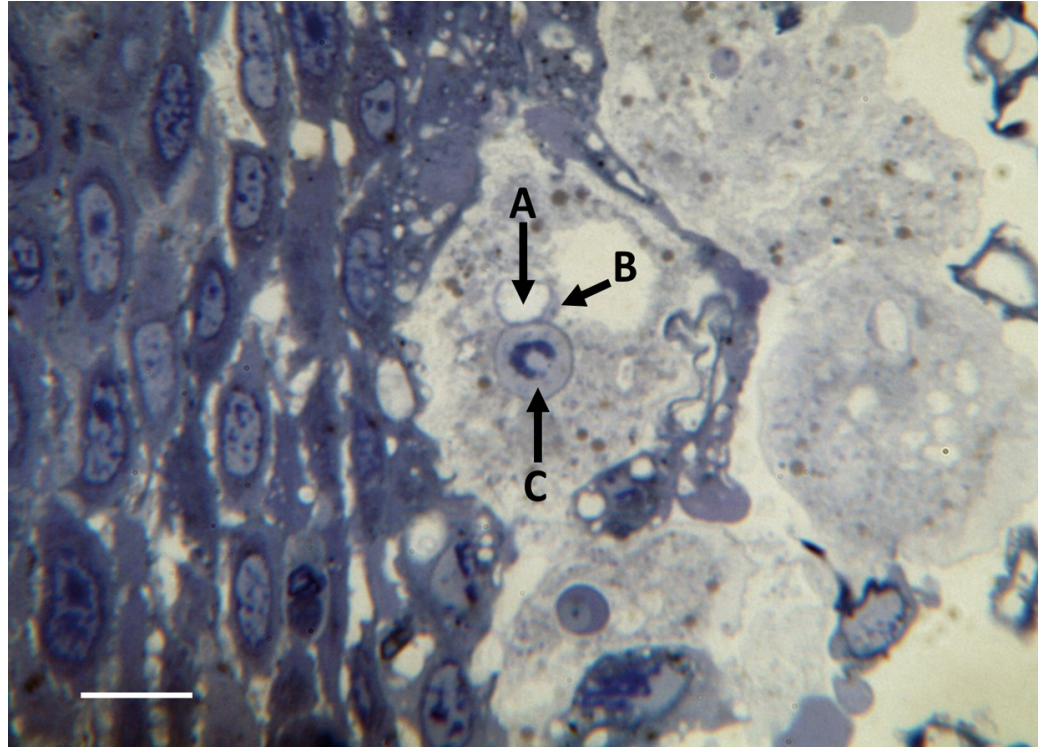

Fig. 4 Atlantic salmon (shedder) from Group 5, 'LB' (H04/14Pp) isolate, sampled at 28 dpc. Extensive vacuolation of the gill epithelium in areas with amoebae. A: Kinetoplast, B: Perkinsela endosymbiont, C: cell nucleus of the

Paramoeba perurans. EMbed 812, magnification $\times 1000$, scale bar $=10 \mu \mathrm{m}$ could be re-isolated on MYA after treatment (Table 6).

In Groups 5 and 6, salmon had initially been bath-challenged with either LB (Group 5) or SS (Group 6). Salmon and wrasse in Groups 5 and 6 were treated with brackish water for $3 \mathrm{~h}$ only. At the time of treatment, the mean gill scores were 4.8 (range $4-5$ ) for salmon and 2.2 (range 1-4) for wrasse in Group 5 and 2.4 (range 2-3) for salmon and 0.2 (range 0-1) for wrasse in Group 6. Prior to treatment at $32 \mathrm{dpc}$, the prevalence of PCR positives was $100 \%$ for both salmon and wrasse in Group 5, whereas $100 \%$ of salmon but only $20 \%$ of the wrasse in Group 6 were PCR positive. There was no decrease in prevalence or amoeba densities following this shortduration treatment, and large numbers of amoebae could be re-isolated on MYA after treatment (Table 6).
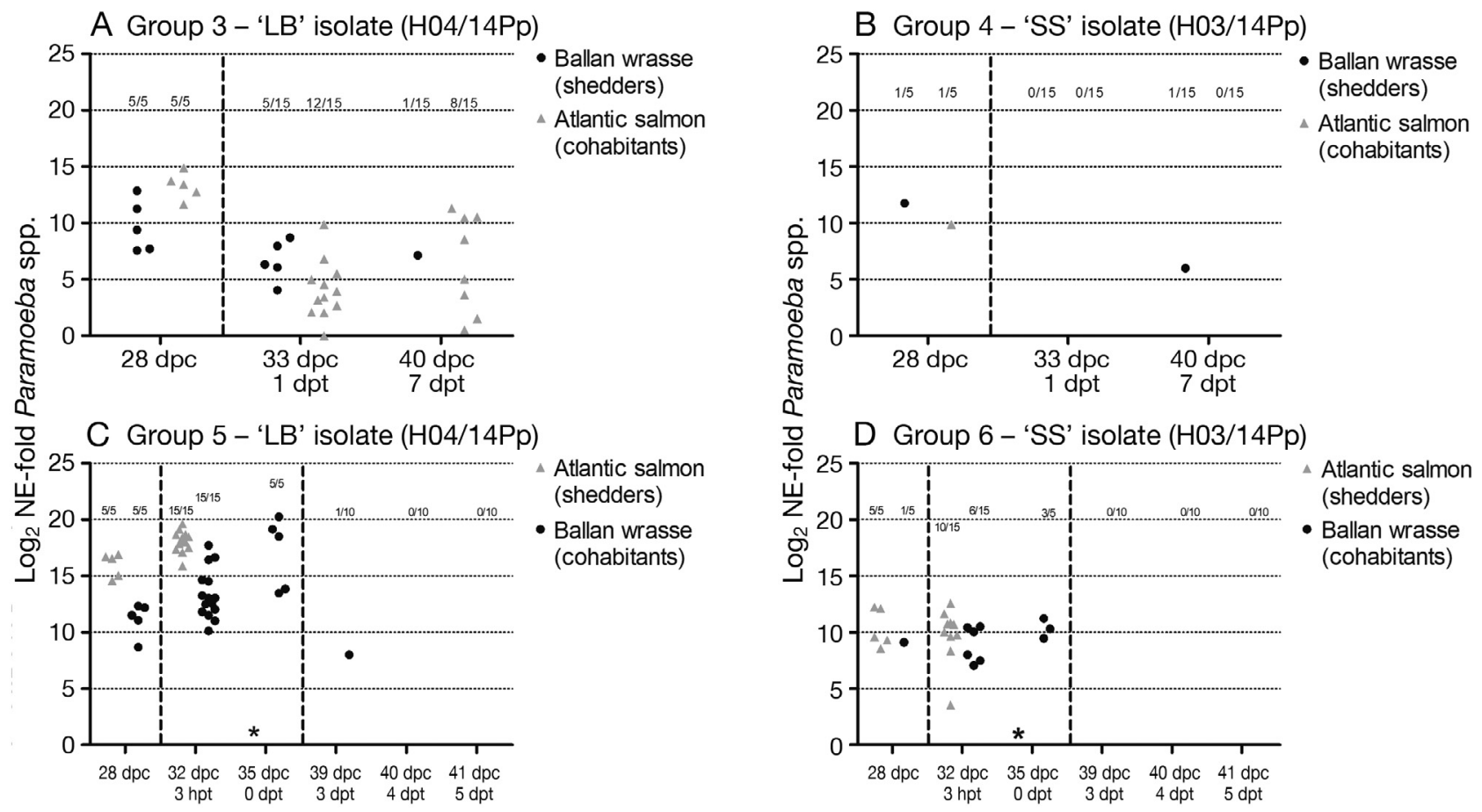

Fig. 5. P. perurans RNA levels in gills after treatment with brackish water. Ct values obtained from real-time RT-PCR were normalized against EF1A for each host species (normalized expression, NE), transformed into fold increase and $\log _{2}$-transformed for the final presentation. The fish in (A) Group 3 and (B) Group 4 were treated for $24 \mathrm{~h}$ with brackish water and samples were taken $1 \mathrm{~d}$ and $1 \mathrm{wk}$ post treatment. The broken line indicates time of treatments. The fish in (C) Group 5 and (D) Group 6 were treated with brackish water for $3 \mathrm{~h}$ only and samples were taken at the end of treatment. Two d later, the remaining salmon were euthanized (marked by an asterisk ${ }^{*}$ ). Three $d$ after treatment, wrasse were re-treated with brackish water for $5 \mathrm{~d}$ and samples were collected on Days 3,4 and 5. Numbers above sampling dates are the number of PCR positives and the number of fish sampled. Different EF1A assays were used for the 2 fish species 
Table 5. Real-time RT-PCR analysis of Paramoeba spp. RNA levels in water from Groups 3 and 4 during and after $24 \mathrm{~h}$ treatment with brackish water. The Paramoeba spp. RNA levels in water during the experiment were normalized against exogenous controls VHSV and SAV. The table shows $\log _{2}$-transformed normalized expression (NE) values (relative to the lowest NE value for water samples), which was seen at 6 dpc in Group 6. nd: Paramoeba spp. RNA not detected

\begin{tabular}{|c|c|c|c|c|}
\hline Time & $\begin{array}{r}\text { Group } 3 \text { (L } \\
\text { Paramoeba sp } \\
\text { vs. VHSV }\end{array}$ & $\begin{array}{l}\text { B isolate)- } \\
\text { RNA levels } \\
\text { vs. SAV }\end{array}$ & $\begin{array}{c}\text { Group } 4 \text { (S } \\
\text { Paramoeba sp } \\
\text { vs. VHSV }\end{array}$ & $\begin{array}{l}\text { S isolate) } \\
\text {. RNA levels } \\
\text { vs. SAV }\end{array}$ \\
\hline $30 \mathrm{~min}$ & 8.77 & 6.43 & nd & nd \\
\hline $90 \mathrm{~min}$ & 9.39 & 7.17 & nd & nd \\
\hline $3 \mathrm{~h}$ & 10.26 & 7.73 & nd & nd \\
\hline $4 \mathrm{~h}$ & 7.33 & 6.97 & nd & nd \\
\hline $5 \mathrm{~h}$ & 8.78 & 6.95 & nd & nd \\
\hline $6 \mathrm{~h}$ & 9.34 & 7.15 & nd & nd \\
\hline $12 \mathrm{~h}$ & 4.66 & 3.99 & nd & nd \\
\hline $24 \mathrm{~h}$ & nd & nd & nd & nd \\
\hline $27 \mathrm{~h}$ & nd & nd & nd & nd \\
\hline
\end{tabular}

euthanized at $35 \mathrm{dpc}$. The ballan wrasse were re-treated with brackish water, but for $5 \mathrm{~d}$ (see Table 1). Prior to treatment, $100 \%$ of the ballan wrasse in Group 5 and $60 \%$ in Group 6 were PCR positive, with high amoeba densities (Fig. 5). The mean gill scores $(\mathrm{n}=5$ per group) were 3.2 and 0.8 in wrasse in Groups 5 and 6, respectively. After $3 \mathrm{~d}$ of treatment with brackish water, a highly significant decrease in amoeba RNA prevalence $(1 / 10$, FET, p < 0.01 ) and density (MW, $\mathrm{p}<0.003$ ) were seen in Group 5. No fish sampled in this group after 4 and $5 \mathrm{~d}$ of treatment were positive (Table 6). The same pattern was seen for wrasse in Group 6: no PCR positives could be identified after being exposed to brackish water for 3,4 or $5 \mathrm{~d}$. It was not possible to re-isolate any amoebae on MYA after $3 \mathrm{~d}$ of treatment from either group (Table 6).
Table 6. Results from brackish water treatments of Groups 3-6. In Groups 3 and 4, where wrasse were bath-challenged, fish were treated with brackish water for $24 \mathrm{~h}$ and sampled at the end of treatment. Additional samples were collected at $7 \mathrm{~d}$ post treatment. In Groups 5 and 6, where salmon were bathchallenged, fish were treated for $3 \mathrm{~h}$ only. In these groups, brackish water treatment was repeated after $3 \mathrm{~d}$ for wrasse only, since the salmon in these groups had been euthanized at $35 \mathrm{dpc}$. This second treatment lasted $5 \mathrm{~d}$, and samples were collected on Days 3,4 and 5. MYA: re-isolation of amoebae on MYA (+/- assay). PCR: PCR detection of amoebae (+/-assay). SE: standard error

\begin{tabular}{|c|c|c|c|c|c|c|c|}
\hline Group & $\begin{array}{c}\text { Fish } \\
\text { species }\end{array}$ & $\begin{array}{l}\text { Treat- } \\
\text { ment }\end{array}$ & PCR & $\begin{array}{c}\text { PCR } \\
\text { prevalence }\end{array}$ & MYA & $\begin{array}{l}\text { Mean gill } \\
\text { score (SE) }\end{array}$ & $\begin{array}{c}\text { Gill score } \\
\text { range }\end{array}$ \\
\hline \multirow[t]{4}{*}{3} & Wrasse & $24 \mathrm{~h}$ & + & $5 / 15$ & - & $1.3(0.25)$ & $0-2$ \\
\hline & & $7 \mathrm{~d}$ & + & $1 / 15$ & - & $0.6(0.16)$ & $0-2$ \\
\hline & Salmon & $24 \mathrm{~h}$ & + & $12 / 15$ & - & $3.9(0.07)$ & $3-4$ \\
\hline & & $7 \mathrm{~d}$ & + & $8 / 15$ & - & $3.5(0.17)$ & $2-4$ \\
\hline \multirow[t]{4}{*}{4} & Wrasse & $24 \mathrm{~h}$ & - & $0 / 15$ & - & $0.3(0.15)$ & $0-2$ \\
\hline & & $7 \mathrm{~d}$ & + & $1 / 15$ & - & $0.0(0.00)$ & 0 \\
\hline & Salmon & $24 \mathrm{~h}$ & - & $0 / 15$ & - & $2.3(0.16)$ & $2-3$ \\
\hline & & $7 \mathrm{~d}$ & - & $0 / 15$ & - & $0.9(0.13)$ & $1-2$ \\
\hline \multirow[t]{5}{*}{5} & Salmon & $3 \mathrm{~h}$ & + & $15 / 15$ & + & $4.9(0.09)$ & $4-5$ \\
\hline & Wrasse & $3 \mathrm{~h}$ & + & $15 / 15$ & + & $2.8(0.28)$ & $1-4$ \\
\hline & & $3 \mathrm{~d}$ & + & $1 / 10$ & - & $0.5(0.22)$ & $0-2$ \\
\hline & & $4 \mathrm{~d}$ & - & $0 / 10$ & - & $0.4(0.22)$ & $0-2$ \\
\hline & & $5 d$ & - & $0 / 10$ & - & $0.6(0.22)$ & $0-2$ \\
\hline \multirow[t]{5}{*}{6} & Salmon & $3 \mathrm{~h}$ & + & $10 / 15$ & + & $2.5(0.17)$ & $1-3$ \\
\hline & Wrasse & $3 \mathrm{~h}$ & + & $6 / 15$ & + & $0.4(0.19)$ & $0-2$ \\
\hline & & $3 d$ & - & $0 / 10$ & - & $0.0(0.00)$ & 0 \\
\hline & & $4 \mathrm{~d}$ & - & $0 / 10$ & - & $0.4(0.22)$ & $0-2$ \\
\hline & & $5 \mathrm{~d}$ & - & $0 / 10$ & - & $0.2(0.20)$ & $0-2$ \\
\hline
\end{tabular}

\section{DISCUSSION}

Paramoeba perurans infections have been detected in a range of fish species worldwide (Kent et al. 1988, Munday et al. 1990, Hvas et al. 2017, Steigen et al. 2018). Many of these species are distantly related, such as Atlantic salmon Salmo salar, ballan wrasse Labrus bergylta and turbot Scophthalmus maximus, which belong to different orders, indicating $P$. perurans has a low host specificity (VKM 2014). Although P. perurans has been found on gills from several fish species after experimental challenge, not all species will develop grossly observable signs of AGD. It has been shown for blue warehou Seriolella brama that some individuals may have no macroscopically visible gill lesions, although amoebae and lesions may be present histologically (Adams et al. 2008). P. perurans infections and typical AGD histopathology may occur in adult ballan wrasse without clear clinical signs of disease (Karlsbakk et al.

\subsubsection{Long treatments ( 3 to $5 \mathrm{~d}$ ): wrasse only}

Due to fish welfare concerns (high gill scores, initial mortality) the salmon in Groups 5 and 6 were
2013). The severity of AGD in farmed populations of Atlantic salmon is usually evaluated using a gill lesion scoring system (Taylor et al. 2009). Gill score is utilised to monitor the progression of AGD in Atlantic 
salmon populations in order to inform treatment decisions. Experience from land-based ballan wrasse rearing facilities has shown that a proportion of wrasse may be $P$. perurans real-time PCR positive during certain periods without macroscopic gill lesions or pathology ( $\mathrm{H}$. Glosvik pers. obs.). In support of this observation, $45 \%$ of wrasse in this study with a gill score of $0(23 / 51)$ tested positive for $P$. perurans using real-time RT-PCR, compared to only $8 \%$ of salmon with a gill score $0(2 / 25)$, indicating that many infected wrasse may not show any apparent gill lesions. Seemingly healthy individuals of several cleaner fish species may be carriers of amoebae and represent a risk of introducing $P$. perurans to new locations (Haugland et al. 2017, Hellebø et al. 2017, Steigen et al. 2018).

The observation that wrasse with no gross gill lesions may be PCR-positive could be due to differences in host response for the 2 fish species. For instance, ballan wrasse have a large number of characteristic eosinophilic cells (Reite 2005, Haugland et al. 2014, 2018). In addition, large numbers of rodlet cells, which are suggested to be important for fighting parasitic infestations, have been found in Labrids (Reite 2005, Reite \& Evensen 2006). Lower gill pathology in wrasse may indicate reduced gill cell proliferation reaction by wrasse. The slow development in gill score and infrequent detections in infected groups may indicate increased tolerance or resistance by the wrasse. Similar trends have been described in brown trout or salmon-trout hybrids (Maynard et al. 2016) and in responding salmon (Taylor et al. 2009) together with lumpfish (Haugland et al. 2017). Indeed, in genetic studies it has been shown that many salmon can become more resistant to AGD following initial infection (Kube et al. 2012).

The present study shows virulence differences between the $2 P$. perurans isolates examined and also differences between wrasse and salmon in susceptibility and how they manifest AGD. The P. perurans isolate LB (H04/14Pp) derived from wrasse was more virulent than the SS isolate (H03/14Pp) from salmon, and the LB isolate seemed more able to proliferate effectively on gills of both salmon and ballan wrasse than the SS isolate. Throughout the study, gill scores and the number of fish with gill scores and PCR positives were higher for both wrasse and salmon in the groups challenged with the LB isolate (Groups 3 and 5) than those in the groups challenged with the SS isolate (Groups 4 and 6). AGD progressed more quickly in the groups that had been challenged with LB than those challenged with SS. For instance, salmon challenged with the former had a mean gill score of 2.8 as early as $14 \mathrm{dpc}$, whereas salmon challenged with SS did not reach similarly high gill score values during the $28 \mathrm{~d}$ the experiment lasted. Mortality was only induced in salmon that had been bathchallenged with the isolate LB (Group 5).

Observed differences between the isolates may not indicate increased virulence of wrasse-derived amoebae compared to those found on salmon. The number of passages in culture differed between the 2 P. perurans isolates used. Both isolates were isolated in 2014, but the SS had been kept 9 mo in culture when the challenge experiment was conducted, whereas LB had been kept for a shorter period (6 wk). Hence the observed virulence differences could possibly be due to attenuation in culture. Crosbie et al. (2012) fulfilled Koch's postulates for AGD in challenge studies with Atlantic salmon using clonal cultures of $P$. perurans held under in vitro conditions. It has been reported that clonal $P$. perurans cultures in continuous culture have lost virulence after prolonged periods (more than 200 passages or $3 \mathrm{yr}$ of culture) (Bridle et al. 2015). Loss of virulence is a feature not uncommon for pathogens kept under continuous in vitro conditions and is also known from related amoebae, such as Paramoeba invadens (Jellett \& Scheibling 1988). In the study by Bridle et al. (2015), loss of virulence could be seen as a reduced ability of amoebae to remain attached to the agar surface and a lack of cytopathic effect when inoculated onto CHSE cells. It was further suggested in the same study that the virulence in fish was lost due to lack of attachment to the gills or a lack of production of extracellular products. Thus, one possible reason for the apparent higher virulence of the LB isolate in this study could be a shorter culture period, and fewer passages in vitro. However, P. perurans clonal isolates that have been kept in continuous culture since 2013 ( $>5 \mathrm{yr}$ ) using the same culture method are still virulent and induce severe disease in salmon when used in challenge studies (L. Andersen pers. obs.). The way cultures are maintained is also likely to affect virulence, as proposed by Crosbie et al. (2012), who found that vigilant sub-culturing of clonal strains is necessary to maintain a virulent strain. In the present study, the $P$. perurans LB isolate from wrasse was split more frequently in the weeks prior to challenge than the SS isolate. It is not known to what degree this could have influenced virulence. Nevertheless, both isolates were treated in the same manner in the last $5 \mathrm{wk}$ prior to the challenge study: the cultures were split, washed with autoclaved salt water and given new media 2 to 3 times a week to remove metabolites and to supply the amoeba cells with nutrients and 
enough space to proliferate. It was recently shown through the use of 16S rRNA Illumina MiSeq sequencing that the bacterial community and abundance may differ between $P$. perurans cultures and temperatures (Benedicenti et al. 2018). Different $P$. perurans clones derived from the same polyculture may differ in virulence (Collins et al. 2017). One factor that may have an effect on virulence and growth properties, such as amoeba numbers and attachment ability, is the bacterial composition of the cultures, which again may reflect a selection during clonal isolation (Benedicenti et al. 2018).

Differences in susceptibility, disease development and shedding could also be observed between the 2 fish species. Atlantic salmon were more susceptible than ballan wrasse and developed AGD faster and to a more severe extent than wrasse (higher gill scores, higher prevalence). The highest gill scores, and highest prevalences, were observed in the groups where salmon acted as shedders, and shedding started earlier from salmon than wrasse shedders. This indicates that the amoebae proliferated more effectively on salmon gills, the increased shedding likely being a result of the higher amoeba densities. Although the SS isolate was less virulent than LB, this appeared not to affect infectivity since fish from all groups bathchallenged with either $P$. perurans isolate were shown to be PCR-positive and to simultaneously develop gill lesions, i.e. the infection dynamics were similar. Using real-time RT-PCR, an increase in the Paramoeba spp. RNA levels in water could be seen from 6 to $11 \mathrm{dpc}$ and throughout the study, but only in the groups where Atlantic salmon had been bathchallenged (Groups 5 and 6). The highest Paramoeba RNA levels in water could be seen for Group 5, where salmon had been bath-challenged with the $P$. perurans isolate LB from wrasse. Amoebae could also be detected in water samples from Group 3 at later stages, from $25 \mathrm{dpc}$, but these likely represented amoebae shed from the cohabitating salmon since the gill scores and RNA levels indicated high levels of amoebae present on gills of salmon at this time. Bathchallenged salmon were shown to be PCR-positive for $P$. perurans at $7 \mathrm{dpc}$, whereas PCR positives could not be detected in bath-challenged wrasse until $14 \mathrm{dpc}$. It cannot be excluded that fish size (and thus gill surface area) might affect the number of amoebae produced during infection to some extent. Gill area scales logaritmically with body mass (Hughes 1984), such that larger fish will have a relatively smaller gill area compared with smaller fish. The wrasse in this study had a mean weight of $20 \mathrm{~g}$, whereas salmon had a mean weight of $80 \mathrm{~g}$ at the beginning of the ex- periment, which means that the larger gill size of salmon used in this study could to some extent have had an impact on the number of amoebae produced during the experiment.

Since the appearance of AGD in seawater-reared Atlantic salmon in Tasmania in the late 1980s, the disease has been managed through frequent freshwater bathing (Munday et al. 1993) for 2 to $3 \mathrm{~h}$ at a time (Parsons et al. 2001). In recent years, AGD has also been treated using hydrogen peroxide in Scotland, Ireland and Norway (Adams et al. 2012). These methods are effective, but costly and logistically challenging, and in many cases, repeated treatments during a production cycle may be necessary. Although the use of freshwater baths is an effective treatment method for euryhaline fish species such as Atlantic salmon, treatment of strictly marine fish species, such as several cleaner fish species, is more challenging (Karlsbakk 2015). In vitro studies on the salinity tolerance of $P$. perurans isolated from ballan wrasse (Karlsbakk et al. 2013) revealed that all amoebae disappeared in brackish water at $15 \%$ after 24 h (E. Karlsbakk \& A. C. B. Einen unpubl. data). Therefore, brackish water treatments have been tried as a defence against AGD in intensive production of ballan wrasse. Exposing wrasse to $15 \%$ salinity over a period of $7 \mathrm{~d}$ successfully resolved AGD without any apparent effect on the fish (O. Breck unpubl. data).

In the present study, we examined this treatment under experimental conditions, and an important aim for the study was to see if it was possible to reduce the treatment time. Thus, treatments of both short ( $3 \mathrm{~h}$ and $24 \mathrm{~h}$ ) and long durations ( $3-5 \mathrm{~d}$ ) were assessed. The $3 \mathrm{~h}$ treatment was ineffective; it did not cause a decrease in amoeba density, and amoebae could readily be cultured from the treated fish. After $24 \mathrm{~h}$, amoeba (i.e. target RNA) prevalence was reduced, but amoebae were still present after treatment. It was not possible to re-isolate $P$. perurans from the fish, which indicates that the positive realtime PCR results seen after $24 \mathrm{~h}$ could be due to remnants of dead amoebae (i.e. RNA, DNA). Analyses of water samples from the tanks also support this explanation, since a significant reduction in the Paramoeba RNA levels was seen after $12 \mathrm{~h}$ and no Paramoeba RNA was detected at 24 and $27 \mathrm{~h}$ after brackish water exposure had been initiated. It is likely that the amoeba load prior to treatment could have an impact on treatment success. Amoebae associated with the surface of the epithelial layers may readily be washed away, but amoebae may also be enclosed in interlamellar cavities in areas 
with extensive epithelial proliferation with fused lamellae (Parsons et al. 2001), which may be partly or completely closed (Kent et al. 1988, Adams \& Nowak 2001). It is possible that amoebae may survive treatments in such cavities (Parsons et al. 2001). However, amoebae in closed cavities tend to show signs of degeneration and necrosis, and may be dying or dead (Adams \& Nowak 2001). Hence, when using molecular methods such as real-time PCR to evaluate treatment efficacy, it is important to bear in mind that the presence of dead amoebae and remnants of these may give positive results although the amoebae are not viable. The observation that 1 wrasse tested positive after $3 \mathrm{~d}$ of treatment using real-time RT-PCR may be due to remnant amoeba RNA/DNA in the gills. Wright et al. (2018) demonstrated that low numbers of amoebae survived on gills of Atlantic salmon exposed daily to $2 \mathrm{~h}$ of freshwater $(\leq 2 \%)$ over $6 \mathrm{~d}$. Hytterød et al. (2017) showed that gill scores in salmon treated with brackish water $(15 \%)$ at $12^{\circ} \mathrm{C}$ for $48 \mathrm{~h}$ were still declining $21 \mathrm{~d}$ after treatment. Treasurer \& Turnbull (2019) examined treatment regimes for lumpfish with AGD and found that treating lumpfish with brackish water $(15 \%)$ for $3 \mathrm{~d}$ was enough to resolve AGD. Based upon our inability to culture amoebae from wrasse treated between 3 and $5 \mathrm{~d}$ in brackish conditions, it is likely that this length of treatment is adequate to clear wrasse of $P$. perurans, indicating that current commercial practice (6-7 d) could be reduced to save on labour and freshwater use.

\section{CONCLUSIONS}

Increased awareness of pathogen status of cleaner fish, especially those with low host specificity such as Paramoeba perurans, is paramount in order to prevent spread of pathogens into new hosts and/ or areas. The recent detection of $P$. perurans in intensive, land-based production of ballan wrasse and in wild caught wrasse show that moving cleaner-fish represent a possible threat to farmed salmon (Karlsbakk et al. 2013, Hellebø et al. 2017, Steigen et al. 2018). Our study shows that brackish water $(<15 \%)$ may be used to efficiently treat wrasse with AGD, and the strategy can be adapted to treat salmon and cleaner-fish for AGD in net pens. A prophylactic holding period in brackish water for cleaner fish, for instance $15 \%$ for $3 \mathrm{~d}$, should be considered before transfer to net pens with salmon.
Acknowledgements. This study was a collaboration between the University of Bergen, the Aquatic and Industrial Laboratory and Marine Harvest, and the study received funding from Marine Harvest, and the Norwegian Seafood Research Fund (Project FHF-901053). The authors thank Sindre Grimen (Aquatic and Industrial Laboratory) for assistance during the experimental amoeba challenge, Emil Høyesen (University of Bergen) for sampling assistance and 3 anonymous reviewers for helpful comments and suggestions.

\section{LITERATURE CITED}

Adams M, Nowak B (2001) Distribution and structure of lesions in the gills of Atlantic salmon, Salmo salar L., affected with amoebic gill disease. J Fish Dis 24: $535-542$

Adams MB, Nowak BF (2004) Sequential pathology after initial freshwater bath treatment for amoebic gill disease in cultured Atlantic salmon, Salmo salar L. J Fish Dis 27: 163-173

Adams MB, Villavedra M, Nowak BF (2008) An opportunistic detection of amoebic gill disease in blue warehou, Seriolella brama Günther, collected from an Atlantic salmon, Salmo salar L., production cage in south eastern Tasmania. J Fish Dis 31:713-717

Adams MB, Crosbie PB, Nowak BF (2012) Preliminary success using hydrogen peroxide to treat Atlantic salmon, Salmo salar L., affected with experimentally induced amoebic gill disease (AGD). J Fish Dis 35:839-848

Andersen L, Hodneland K, Nylund A (2010) No influence of oxygen levels on pathogenesis and virus shedding in Salmonid alphavirus (SAV)-challenged Atlantic salmon (Salmo salar L.). Virol J 7:198

* Benedicenti O, Secombes CJ, Collins C (2019) Effects of temperature on Paramoeba perurans growth in culture and the associated microbial community. Parasitology 146:533-542

Bjordal Å (1991) Wrasse as cleaner-fish for farmed salmon. Prog Underw Sci 16:17-28

* Blanco Gonzalez E, de Boer F (2017) The development of the Norwegian wrasse fishery and the use of wrasses as cleaner fish in the salmon aquaculture industry. Fish Sci 83:661-670

Bridle AR, Davenport DL, Crosbie PB, Polinski M, Nowak BF (2015) Neoparamoeba perurans loses virulence during clonal culture. Int J Parasitol 45:575-578

Brooker AJ, Papadopoulou A, Gutierrez C, Rey S, Davie A, Migaud $H$ (2018) Sustainable production and use of cleaner fish for the biological control of sea lice: recent advances and current challenges. Vet Rec 183:383

Collins C, Hall M, Bruno D, Sokolowska J and others (2017) Generation of Paramoeba perurans clonal cultures using flow cytometry and confirmation of virulence. J Fish Dis 40:351-365

Crosbie PBB, Bridle AR, Leef MJ, Nowak BF (2010) Effects of different batches of Neoparamoeba perurans and fish stocking densities on the severity of amoebic gill disease in experimental infection of Atlantic salmon, Salmo salar L. Aquacult Res 41:e505-e516

Crosbie PBB, Bridle AR, Cadoret K, Nowak BF (2012) In vitro cultured Neoparamoeba perurans causes amoebic gill disease in Atlantic salmon and fulfils Koch's postulates. Int J Parasitol 42:511-515 
Culling CFA, Allison RT, Barr W (1985) Haematoxylin and its counterstains. In: Culling CFA (ed) Cellular pathology technique. Butterworth \& Co, London, p 111-152

Directorate of Fisheries (2017) Cleanerfish (lumpfish and wrasse). Directorate of Fisheries, Bergen. https://www. fiskeridir.no/English/Aquaculture/Statistics/CleanerfishLumpfish-and-Wrasse

Duesund H, Nylund S, Watanabe K, Ottem KF, Nylund A (2010) Characterization of a VHS virus genotype III isolated from rainbow trout (Oncorhychus mykiss) at a marine site on the west coast of Norway. Virol J 7:19

Feehan CJ, Johnson-Mackinnon J, Scheibling RE, LauzonGuay JS, Simpson AGB (2013) Validating the identity of Paramoeba invadens, the causative agent of recurrent mass mortality of sea urchins in Nova Scotia, Canada. Dis Aquat Org 103:209-227

*Gunnarsson GS, Blindheim S, Karlsbakk E, Plarre H and others (2017) Desmozoon lepeophtherii (microsporidian) infections and pancreas disease (PD) outbreaks in farmed Atlantic salmon (Salmo salar L.). Aquaculture 468:141-148

*Haugland GT, Ronneseth A, Wergeland HI (2014) Flow cytometry analyses of phagocytic and respiratory burst activities and cytochemical characterization of leucocytes isolated from wrasse (Labrus bergylta A.). Fish Shellfish Immunol 39:51-60

*Haugland GT, Olsen AB, Rønneseth A, Andersen L (2017) Lumpfish (Cyclopterus lumpus L.) develop amoebic gill disease (AGD) after experimental challenge with Paramoeba perurans and can transfer amoebae to Atlantic salmon (Salmo salar L.). Aquaculture 478:48-55

Haugland G, Rønneseth A, Wergeland H (2018) Immunology and vaccinology of lumpfish and wrasse. In: Treasurer JW (ed) Cleaner fish biology and aquaculture applications. 5M Publications, Sheffield

Hellebø A, Stene A, Aspehaug V (2017) PCR survey for Paramoeba perurans in fauna, environmental samples and fish associated with marine farming sites for Atlantic salmon (Salmo salar L.). J Fish Dis 40:661-670

Hodneland K, Endresen C (2006) Sensitive and specific detection of Salmonid alphavirus using real-time PCR (TaqMan). J Virol Methods 131:184-192

Hughes GM (1984) Measurement of gill area in fishes: practices and problems. J Mar Biol Assoc UK 64:637-655

Hvas M, Karlsbakk E, Mæhle S, Wright DW, Oppedal F (2017) The gill parasite Paramoeba perurans compromises aerobic scope, swimming capacity and ion balance in Atlantic salmon. Conserv Physiol 5:cox066

Hytterød S, Andersen L, Hansen H, Blindheim S, Poppe T, Kristoffersen A, Mo T (2017) AGD-behandlingsstrategier-dose-respons-studier med hydrogenperoksid og ferskvann. Veterinærinstituttets rapportserie nr. 10-2017

Jellett JF, Scheibling RE (1988) Virulence of Paramoeba invadens Jones (Amoebida, Paramoebidae) from monoxenic and polyxenic culture. J Protozool 35:422-424

Karlsbakk E (2015) Amøbisk gjellesykdom (AGD) — litt om den nye plagen. In: Bakketeig IE, Gjøsæter $H$, Hauge $M$, Sunnset BH, Toft KØ (eds) Havforskningsrapporten 2015. Havforskningsinstituttet, Bergen, p 33-35

Karlsbakk E, Olsen AB, Einen ACB, Mo TA and others (2013) Amoebic gill disease due to Paramoeba perurans in ballan wrasse (Labrus bergylta). Aquaculture 412413:41-44

Kent ML, Sawyer TK, Hedrick RP (1988) Paramoeba pemaquidensis (Sarcomastigophora: Paramoebidae) infesta- tion of the gills of coho salmon Oncorhynchus kisutch reared in sea water. Dis Aquat Org 5:163-169

Kube PD, Taylor RS, Elliott NG (2012) Genetic variation in parasite resistance of Atlantic salmon to amoebic gill disease over multiple infections. Aquaculture 364-365: 165-172

* Leclercq E, Davie A, Migaud H (2014) Delousing efficiency of farmed ballan wrasse (Labrus bergylta) against Lepeophtheirus salmonis infecting Atlantic salmon (Salmo salar) post-smolts. Pest Manag Sci 70:1274-1282

Marcos-López M, Rodger HD, O'Connor I, Braceland M, Burchmore RJS, Eckersall PD, Maccarthy E (2017) A proteomic approach to assess the host response in gills of farmed Atlantic salmon Salmo salar L. affected by amoebic gill disease. Aquaculture 470:1-10

Maynard B, Taylor RS, Kube PD, Cook MT, Elliott NG (2016) Salmonid heterosis for resistance to amoebic gill disease (AGD). Aquaculture 451:106-112

Munday BL, Foster CK, Roubal FR, Lester RJG (1990) Paramoebic gill infection and associated pathology of Atlantic salmon, Salmo salar, and rainbow trout, Salmo gairdneri, in Tasmania. In: Perkins RO, Cheng TC (eds) Pathology in marine science. Academic Press, San Diego, CA, p 215-222

Munday BL, Lange $\mathrm{K}$, Foster C, Lester R, Handlinger J (1993) Amoebic gill disease in sea-caged salmonids in Tasmanian waters. Tasman Fish Res 28:14-19

* Munday B, Zilberg D, Findlay V (2001) Gill disease of marine fish caused by infection with Neoparamoeba pemaquidensis. J Fish Dis 24:497-507

Nowak BF, Young N, Morrison RN, Attard MG, Vincent BN, Crosbie P (2008) Aquafin CRC - Atlantic salmon aquaculture subprogram: establishment of challenge for AGD. Report Aquafin CRC Project 3.4.1(3), FRDC Project No. 2004/215. University of Tasmania, Launceston

Nowak B, Valdenegro-Vega V, Crosbie P, Bridle A (2014) Immunity to amoeba. Dev Comp Immunol 43:257-267

* Nylund A, Pistone D, Trosse C, Blindheim S, Andersen L, Plarre H (2018) Genotyping of Candidatus Syngnamydia salmonis (Chlamydiales; Simkaniaceae) co-cultured in Paramoeba perurans (amoebozoa; Paramoebidae). Arch Microbiol 200:859-867

Oldham T, Rodger H, Nowak BF (2016) Incidence and distribution of amoebic gill disease (AGD) - an epidemiological review. Aquaculture 457:35-42

Olsvik PA, Lie KK, Jordal AE, Nilsen TO, Hordvik I (2005) Evaluation of potential reference genes in real-time RTPCR studies of Atlantic salmon. BMC Mol Biol 6:21

Parsons H, Nowak B, Fisk D, Powell M (2001) Effectiveness of commercial freshwater bathing as a treatment against amoebic gill disease in Atlantic salmon. Aquaculture 195:205-210

* Powell MD, Parsons HJ, Nowak BF (2001) Physiological effects of freshwater bathing of Atlantic salmon (Salmo salar) as a treatment for amoebic gill disease. Aquaculture 199:259-266

Reite OB (2005) The rodlet cells of teleostean fish: their potential role in host defence in relation to the role of mast cells/eosinophilic granule cells. Fish Shellfish Immunol 19:253-267

Reite OB, Evensen O (2006) Inflammatory cells of teleostean fish: A review focusing on mast cells/eosinophilic granule cells and rodlet cells. Fish Shellfish Immunol 20:192-208

Simon P (2003) Q-Gene: processing quantitative real-time RT-PCR data. Bioinformatics 19:1439-1440 
Skiftesvik AB, Bjelland RM, Durif CM, Johansen IS, Browman HI (2013) Delousing of Atlantic salmon (Salmo salar) by cultured vs. wild ballan wrasse (Labrus bergylta). Aquaculture 402-403:113-118

Smørås C (2014) Betydning av Paranucleospora theridion og Salmonid Alfavirus (SAV) for utvikling av sykdom hos Atlantisk laks (Salmo salar L.). MSc thesis, University of Bergen

Steigen A, Nylund A, Karlsbakk E, Akoll P and others (2013) 'Cand. Actinochlamydia clariae' gen. nov., sp. nov., a unique intracellular bacterium causing epitheliocystis in catfish (Clarias gariepinus) in Uganda. PLOS ONE 8: e66840

Steigen A, Nylund A, Plarre H, Watanabe K, Karlsbakk E, Brevik O (2018) Presence of selected pathogens on the gills of five wrasse species in western Norway. Dis Aquat Org 128:21-35

Taylor RS, Muller WJ, Cook MT, Kube PD, Elliott NG (2009) Gill observations in Atlantic salmon (Salmo salar, L.) during repeated amoebic gill disease (AGD) field exposure and survival challenge. Aquaculture 290:1-8

Editorial responsibility: Dieter Steinhagen, Hannover, Germany
Treasurer JW (2012) Diseases of north European wrasse (Labridae) and possible interactions with cohabited farmed salmon, Salmo salar L. J Fish Dis 35:555-562

* Treasurer J, Turnbull T (2019) Tolerance of lumpfish, Cyclopterus lumpus, to freshwater bath treatment for amoebic gill disease, Neoparamoeba perurans, infection and efficacy of different treatment regimens. J World Aquacult Soc 50:42-53

VKM (Norwegian Scientific Committee for Food Safety) (2014) Panel on Animal Health and Welfare: Risk assessment of amoebic gill disease. VKM Report 2014:11. VKM, Oslo

* Wright DW, Nowak B, Oppedal F, Crosbie P, Stien LH, Dempster T (2018) Repeated sublethal freshwater exposures reduce the amoebic gill disease parasite, Neoparamoeba perurans, on Atlantic salmon. J Fish Dis 41:1403-1410

* Young ND, Crosbie PB, Adams MB, Nowak BF, Morrison RN (2007) Neoparamoeba perurans n. sp., an agent of amoebic gill disease of Atlantic salmon (Salmo salar). Int J Parasitol 37:1469-1481

Y Young ND, Dyková I, Nowak BF, Morrison RN (2008) Development of a diagnostic PCR to detect Neoparamoeba perurans, agent of amoebic gill disease. J Fish Dis 31:285-295

Submitted: July 29, 2019; Accepted: April 3, 2020

Proofs received from author(s): June 15, 2020 